
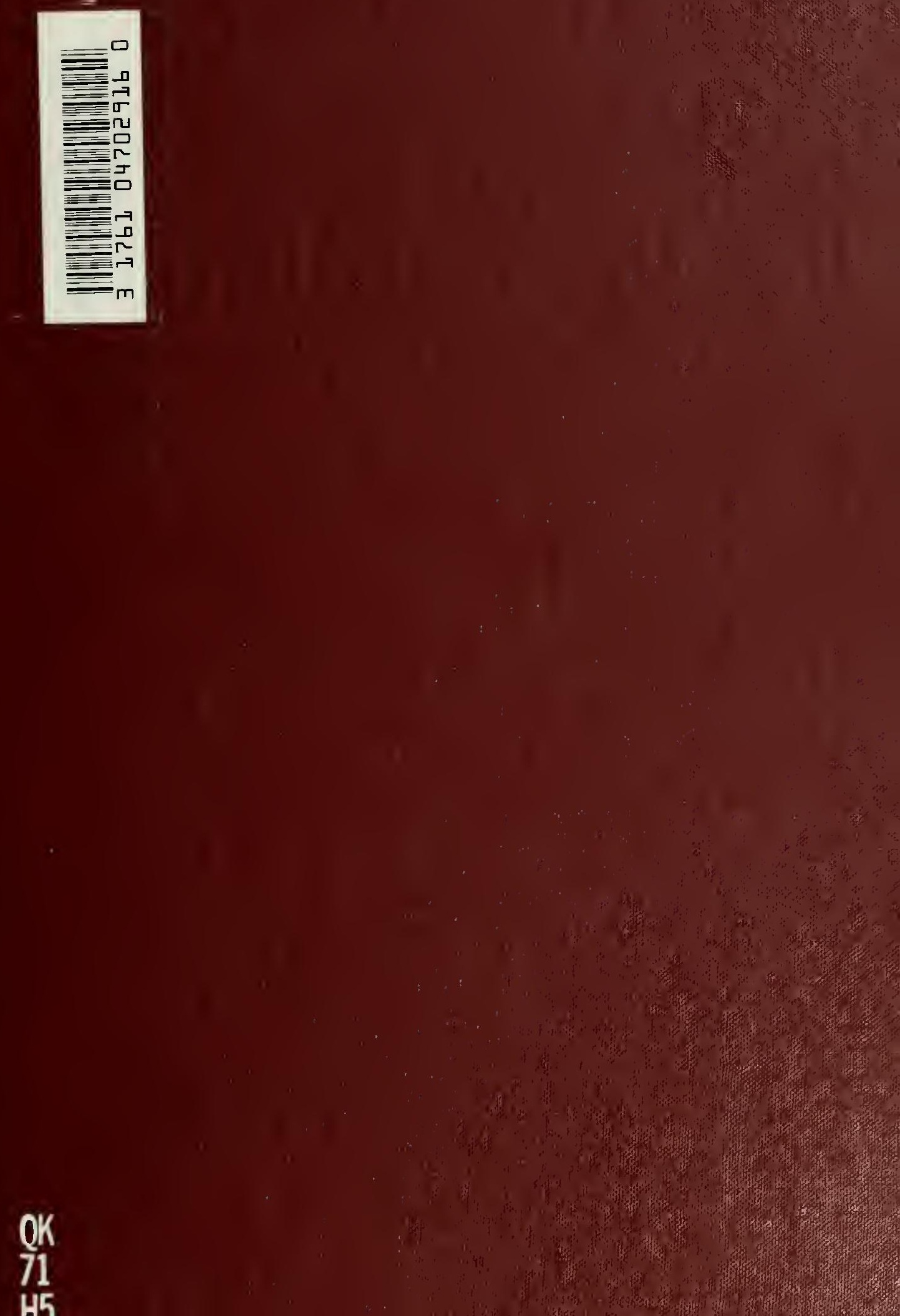
Digitized by the Internet Archive in 2008 with funding from Microsoft Corporation 




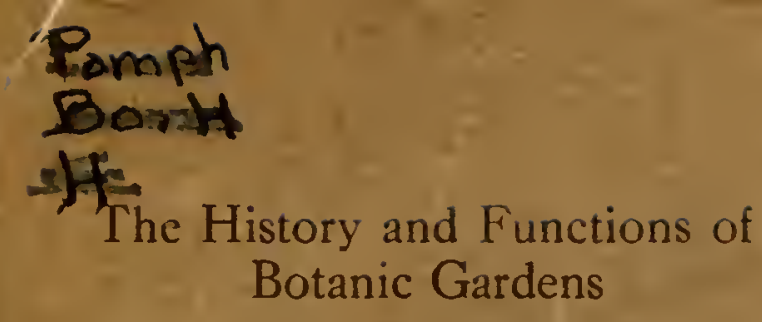

A. W. HrLI.

Reprinted from Axxats of the MIrssouri Botaxical GARDEN 2: 185-240. February-April, 1915

A paper read by invitation at the Twentyfifth Anniversary Celebration of the Missouri Botanical Garden, October 15, 1914. 



\title{
THE HISTORY AND FUNCTIONS OF BOTANIC GARDENS
}

\author{
ARTHUR W. HILL, M.A., F.L.S. \\ Assistant Director, Royal Botanio Gardens, Kew
}

There are three things which have stimulated men throughout the ages to travel far and wide over the surface of the globe, and these are gold, spices and drugs. It is to the two latter of these universal needs of man that we may trace the origin and foundation of botanic gardens.

The value of spices has led to the foundation of more than one botanic garden in the tropics, while to the necessity for drugs must be attributed the formation of the earliest botanic gardens in Europe.

Before entering more fully into the history of the founding of the various botanic gardens it may be pointed out that progress in the science of botany and the establishment of gardens were by no means contemporaneous. To the Greeks, for instance, we owe the foundation of our knowledge of the classification of plants, and these early botanists were assiduous in collecting plants from all available sources and in drawing up accurate descriptions.

Little interest, however, would appear to have been aroused in them to cultivate the plants they so carefully described, and the only record we have of the existence of anything of the nature of a botanic garden is the mention of Aristotle's Garden at Athens which he bequeathed to Theophrastus, by whom it was newly equipped and improved.

Prior to the interest displayed by the Greeks in the vegetation of the earth and quite independent of their influence we find evidence of the formation of gardens in Egypt, Assyria, China, and subsequently in Mexico-gardens not strictly botanic in our more modern sense but enclosures ${ }^{1}$ set apart

1 See Greene, E. L. Landmarks of botanical history. Smithsonian Misc. Coll. $54^{1}$ :pp. 56-57. 1909. No douht Theophrastus (370-286 or 262 B. C.) gained his intimate knowledge of plants very largely from the specimens cultivated in this early Athenian garden.

ANN. MO. BOT. GARD., VOL. 2, 1915 
for the cultivation of plants of some definite economic or aesthetic value.

In considering the history of this subjeet we look back to the earliest history of mankind, with which gardening in some form is inseparably connected, for, as Francis Bacon reminds us :

"God Almightie first planted a Garden and indeed it is the Purest of Humane Pleasures. It is the greatest refreshment to the spirits of man; without which Buildings and Palaces are but grosse Handyworkes: and a man shall ever see that when ages grow to eivility and elegancie men come to Build stately sooner than to garden finely as if gardening were the greater Perfection."

We are still exereised to seek out and grow "every tree that is pleasant to the sight and good for food," and the "tree of life" also in the midst of the garden is ever the object of our inquiries. It would be well indeed if at this present time we could discover that tree whose leaves were to be "for the healing of the Nations."

The earliest garden of which we have any representation is the Royal Garden of Thotmes in of about the year 1000 B. C., which was planned by Nekht, head gardener of the gardens attached to the Temple of Karnak. ${ }^{1}$ This Royal Garden, rectangular in outline, with its rows of date and branched doum palms and with its vine pergola and lotus tanks, was probably in the nature of a pleasure garden, while those attached to the temples may well have been of more economic importance. The Chinese, ${ }^{2}$ however, should, as might be supposed, be eredited with being the real founders of the idea of botanie gardens, since it is elear that eollectors were despatched to distant parts and the plants brought back were eultivated for their economic or medicinal value. The semimythical Emperor Shen Nung, of the twenty-eighth century B. C., is considered to be the Father of Medicine and Husbandry and is said to have tested the medical qualities of herbs and diseovered medieines to eure diseases. If this be

1 See Holmes, E. M. Horticulture in relation to medicine. Roy. Hort. Soc., Jour. 3I : pp. 44-45. f. 11. 1906.

'Bretschneider, F Botanicon sinieum. China Branch Roy. Asiatic Soc., Jour. N. S. 25 : p. 24.1893. 
correct, it was but a repetition of history which led to the foundation of the monastic herb gardens in the ninth century A. D., and the subsequent institution of botanic or herb gardens in connection with the medical faculties of the earliest European universities.

We learn from Bretschneider also that the Han Emperor Wu Ti (140-86 B. C.) planted a number of rare herbaceous plants and trees brought from the southern regions in the garden of his palace and the following plants have been identified from the list enumerated: Nephelium Litchi, $N$. logan, Areca Catechu, the banana, Quisqualis indica, Canarium album, C. Pimela, Cinnamomum Cassia, Canna indica, and sweet oranges. He also despatched officers to the northwestern frontiers of China, who brought back reports on the productions of this region. Ancient Chinese authors ascribe to $\mathrm{Wu}$ Ti the introduction of the vine, pomegranate, saffflower, common bean, cucumber, lucerne, coriander, walnnt, etc.

It is a fact of no small interest in this connection to remember that the modern world has turned to China and that her rast botanical treasures have only recently been seriously explored through the enterprise of British, French, and American botanists for the enrichment of our botanic gardens and pleasure grounds.

The establishment of gardens in Mexico is a noteworthy fact-though we have but little information about themsince their origin must have been autochthonous and independent of such institutions in the old World. Prescott ${ }^{1}$ tells $\mathrm{ns}$, and we have reason to believe his account to be true, that Montezuma had extensive gardens filled with fragrant shrubs and flowers and especially with medicinal plants. New Spain, indeed, furnished more important species of medicinal plants perhaps than any other part of the world, and their virtues were understood by the Aztecs, who are credited with having studied medical botany as a science. The gardens at Iztapalan $^{2}$ and Chalco ${ }^{3}$ are said to have been stocked with

${ }^{1}$ Prescott, W. H. Conquest of Mexico 2: pp. 110,111. 1847. [3rd cd. London.]

2 Ibid. pp. 60 and 61 .

Ibid. 3: p. 37. 1847; Clavigero, D. F. S. Stor. del Mcssico 2: p. 153. 
trees and plants scientifically arranged, and the gardens at Chalco, which were preserved after the Conquest, furnished Hernandez with many of the specimens described in his book. ${ }^{1}$

The eases cited, however, have little more than an academic interest for us and have in no way influenced the foundation of modern botanic gardens. These we can trace back to monastic institutions and probably to the famous injunctions of Charlemagne, ${ }^{2}$ the direct outcome of which was the establishment, among others, in the ninth century, of the "hortus" at St. Gall with the attendant "herbularis," or Physic Garden, this latter being the precursor of the physic gardens established in connection with the medical facultios of the Italian and other universities in the sixteenth century.

It is fortunate that we have preserved to us exact details of the "hortus" and "herbularis" at St. Gall, with lists of the plants cultivated therein. ${ }^{3}$ The hortus was an oblong enclosure containing eighteen rectangular beds, while the Physic Garden, or herbularis (see fig. 1), formed a square set with similar beds and having the doctor's house close at hand.

The monks being bound to live on pulse, vegetables and fruits and to gather the same for themselves, the garden and its cultivation were of especial importance in the monastery. To the fostering care of the monks and to their knowledge of drugs, horticulture and botany, in common with other arts and sciences, we owe a debt the magnitude of which it is difficult to estimate.

We do well to recall at this point the services rendered in recent years to the biological sciences by the labors of Gregor Mendel in the monastic garden at Brunn, if only to emphasize how widespread and far-reaching are the functions involved in the true idea of the botanic garden.

The fourteenth and fifteenth centuries, as is woll kuown, were times of a great revival and interest in learning, and

${ }^{1}$ Hernandez, F. Nova plantarum animalium et mineralium Mexieanormm historia. Rome, 1651.

${ }^{2}$ Holmes, E. M. Horticulture in relation to medicine. Roy. Hort. Soe, Jour. $31:$ p. 50.1906.

Arehacological Inst., Jour. 5: p. 113; see also Amherst, A. History of gardening in England p. 5. 1896. [2nd cd.] 
the science of botany received its due share of attention. Unfortunately, energy was chiefly employed in attempting to identify the plants named by the Greek writers with those of Western Europe and progress in the science was only fitful. The compilation of herbals was the main occupation
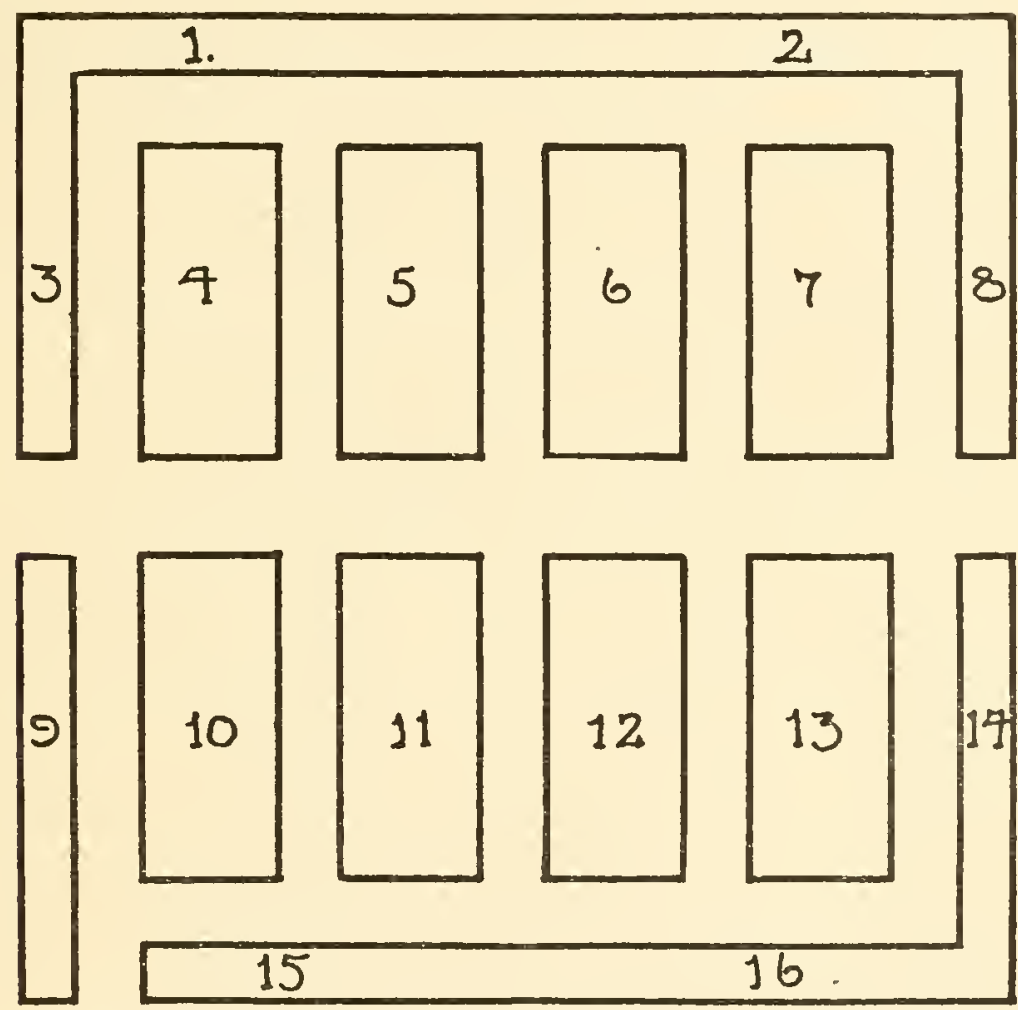

Fig. 1. Monastery of St. Gall. Physic Garden: 1, Fasiolo; 2, Sataregia; 3 , Rosas; 4, Sisimbria ; 5, Cumino; 6 , Lubestico; $\gamma$, Feniculum; 8, Costo; 9, Lilium; 10, Salvia; 11, Ruta; 12, Gladiola; 13, Pulegium; 1., Fenugraeca; 15, Mentha; 16, Rosmarino. The Cemetery contained apples, pears, peaches, mulberries, plums, laurels, figs, hazelnuts, service, chestnuts, medlars, quinces, almonds, and walnuts.

of industrious botanists and many of these works, though of little botanical value to-day, can be treasured by us as storehouses of artistic beauty.

With the real growth in the kuowledge of plants and their uses there grew up also a mass of superstitious information, 
partly founded on old tradition, increased with the importation of strange drugs, ${ }^{1}$ and partly no doubt invented by the herbalists and drug-sellers to prevent any infringement of their monopoly in plants of real or supposed medicinal virtue, and to frighten the ignorant from attempting to collect the plants for themselves.

The faint resemblance of the mandrake root to the human form, for instance, probably suggested its use as a remedy for sterility; it is still sold to-day in Egypt as a charm. Its use may have led to the discovery of its anaesthetic qualities since it was used in ancient times for this purpose, and the legends which abounded as to the danger of death to those who gathered the root may have been circulated in order to try to prevent its use for criminal purposes.

It was largely owing to the need of protecting the doctor and apothecary against the drug-sellers that the growing of "simples" in recognized gardens had its origin. As the seats of the medical profession were established in the universities and monasteries, these institutions set apart definite enclosures for the eultivation of medicinal herbs, the "simplicia" or "simples" from which the "remedia composita" were prepared by the apothecaries.

Since the universities and monasteries were generally situated in towns, their physic gardens were usually small, and on the continent of Europe we still see these ancient gardens, which have been gradually transformed into the botanic gardens of the universities.

In connection witl the growth of learning and increase of observation which is noticeable in the arts and sciences at this time of renaissance, it is strange that biology was still so largely under the thrall of superstition and curious invention. Reference to the early herbals, such as the 'Buch der Natur' (1475), the 'Herbal of Apuleins' (1484), and the 'Grant Herbier' (1526), shows both as regards text and illustration a persistent state of ignorance of facts, which conld easily have been remedied by observation, and possibly does not represent

\footnotetext{
"Medicinal plants were imported from the Continent in a dry state, henee the English word "drug," which is part of the Anglo-Saxon verb "drigan," to dry.
} 
the true state of the knowledge of the more competent medical botanists of the period. The herbal of Brunfels (1530), with its beautiful and accurate illustrations but indifferent text, and those of Bock, Fuchs, Cordus, and many others, may be taken as evidence of the rapid advance that was taking place in the knowledge of plants, though the fabulous and mythical still found adherents even amongst the most learned.

Private physic gardens, as distinct from the monastic herbaries, existed towards the end of the fifteenth century, and some of these developed into municipal gardens for the growing of "simples." The botanic garden at Padua, which appears to have been one of the earliest of these gardens, was founded in 1545 on the exact spot which it now occupies near the church of S. Antonio and S. Giustino. The garden owes its origin to the sound suggestion put forward at the end of the year 1542 by Francesco Bonafede, who in 1533 had founded the chair of "simples" (Lectura Simplicinm) - the first in Europe-at the University of Padua.

This garden is of especial interest, as not only have we an excellent account of it written by de Visiani, ${ }^{1}$ but also because it is preserved very largely in its original condition. The circular wall by which it is enclosed, though not the original one built in 1551, occupies the same site, and was rebuilt between 1700 and 1707; within the wall the garden is laid out in numerous little beds with stone edgings. The garden underwent many vicissitudes and fell into cousiderable decay, but in the year 1837 it was thoroughly restored, and the arrangement of the beds may well be a restoration of the original condition of the garden. In any case it affords an excellent example of the type of geometrical garden illustrated in horticultural books published at the end of the sixteenth and beginning of the seventeenth centuries, ${ }^{2}$ which for so long a time dominated garden design on the Continent.

' de Visiani, R. Dell' origine ed anzianita dell' orto botanico di Padova. Padua, 1839. Saccardo, P. A. L'orto botanico di Padova nel 1895. pl. 1-8. f. 1. Padua, 1895.

${ }^{2}$ See illustrations of the gardens of De Vries, 1580-1583, reproduced by Sir F. Crisp in 'Illustrations of some mediaeval gardens,' 1914; and ef. Mariani, Florilegium renovatum et auctum. Frankfurt, 1641. 
It is to be regretted that the principal features have been somewhat obscured by the growth of trees, but the ground plan fortunately remains mnaltered. Pisa in 1544, Bologna in 1547, and others, ${ }^{1}$ quickly followed the lead given by Padua. We are fortunate in possessing an elaborate plan of the Pisan garden published in Tilli's catalogue ${ }^{2}$ of 1723 with a list of the plants cultivated in the various beds and enclosures, the latter being here reproduced.

\section{EXPLICATIO \\ PROSPECTUS \\ HORTI PISANI}

1. Topiarium magnum instar Tentorii, Cupressinis Arboribus flexilibus, \& ferreis catenis circumdatum.

2. Umbraculum primum venustum, opere topiario, Citris Arboribus, ac Citroidibus poma suaveolentia ferentibus instructum, \& fontibus ornatum.

3. Umbraculum alterum Citroidibus Florentinis repletum.

4. Vaporarium pro Plantis Americanis.

5. Vaporarium gestatorium.

6. Locus pro Plantis Aegyptiis aquam respuentibus.

7. Vaporarium cum laminis vitreis fixum ad semina vegetanda.

8. Paries per totam longitudinem Aurantiorum Olyssipponensium, aliarumque: Arborum poma sustinens.

9. Fenestrae Hypocausti.

10. Fenestrae Hybernaculi.

11. Platea cum variis Aloës Plantis.

12. Nemus exoticarum, \& indigenarum Arborum.

13. Hydrophylacia, seu Castella.

14. Locus pro Plantis montanis, \& Sylvestribus.

15. Laboratorii Chimici, in quo Anthlia Pneumatica reperitur, pars externa IIortum respiciens. Supra verò extat infundibulum ad pluviam recipiendam, de qua fusè D. G. Derham in suis transactionibus, ac etiam in Demonstr. cap. iii. pag. 23. mentionem facit; eadem pars externa variis fontibus, ac lapidibus figuratis est ornata; ibi scilicet reperiuntur Astroites, qui in Metallotheca Mercati pag. 235. \& Corallites, Placentae, Lapis Lumbricatus cap. 55. quorum etiam aliqui sunt Lapides Cerebriformes, an huc allati sint ex Sicilia, vel Sardinia, aut ex Jamaica, ut Rayus Hist. Tom. iii. pag. 5. ex Sloanis verbis, adhue nescimus.

${ }^{1}$ Botanic gardens were founded in Zurich, 1560; Bologna, 1568; Leyden, 1577 ; Leipzig, 1579; Montpellier, 1598; Paris, 1597, known as Jardin des Plantes after 1635; Heidelberg, before 1600; Giessen, 1605; Strasburg, 1620; Oxford, 1621; Jena, 1629; Upsala, 1657; Chclsea, 1673; Rerlin, 1679; Edinburglı, 16s0; Amsterdam, 1682. See also foot-note, p. 209.

- Tilli, M. A. Catalogus plantarum Horti Pisani. Florence, 1723. 
16. Pergulae Laurorum.

17. Prunorum diversae Arbores murum tegentes.

18. Aurantiorum Arbores.

Divisiones Plantarum secundum earum propriam naturam, areolis contentarum.

19. Locus Herbis tantum Hortensibus repletus.

20. Locus Acanaceis Plantis.

21. Locus Plantis Umbelliferis.

22. Locus Plantis Palustribus.

23. Locus Plantis Venenatis.

24. Locus Plantis Odoratis.

25. Locus Plantis Bulbosis.

26. Florilegii locus.

27. Vaporarium fixum, ac fimo equino repletum, ubi Ananas, \& similes Plantae exoticae aluntur.

2S. Ostium primum.

29. Ostium Laboratorii Chimici, ubi Anthlia reperitur, aditum respiciens. 1

30. Ostium alterum Horti publici: intus insignium Botanicorum Virorum effigies visuntur.

31. In Tecto Infundibulum pluviam recipiens.

32. Paries Aurantiis Hermaphroditis ornata.

33. Platea.

34. Ubi Muscae odoratae D. Chimentelli oriuntur.

35. Aditus qui ad ostium Viae publicae ducit: ibi Balenae, \& Physeteris ossa suspensa, ut pagina 4. hujus Catalogi, ubi de Agarico agitur.

36. Fenestrae Domus Custodis.

37. Fenestrae Musei In earum medio Inscriptio haec legitur.

The beds at Pisa are arranged on the geometrical plan and the picture of the garden shows a perfect specimen of the typical formal garden of the end of the sixteenth century. The plants were grouped chiefly according to their properties and morphological characteristics : Thus one finds beds for poisonous plants, prickly plants, smelling plants, bulbs and marsh plants. "Aloes" (Aloe, Gasteria, etc.) were also grown and are figured in the catalogue and there was a "vaporarium pro plantis Americanis.",

The lectures on "simples" delivered at the early Italian universities were not at first accompanied by demonstrations upon living specimens, but the growing of the plants in

1 This and the remaining buildings, etc., are shown on a separate plan which is not reproduced here. 
definite gardens led to the establishment of demonstrations upon living specimens of the medicinal plants, and at Padua sixteen year's after the foundation of the garden, a separation was made of the "Leetura" from the "Ostensio simplicium," or demonstration of living plants.

Botany, however, in all these early universities to which gardens were attached was merely ancillary to medieine. At Montpellier, for instance, the same professor tanght anatomy in winter and botany in summer, and as late as 1773 anatomy, surgery and botany formed the subjects for one and the same professor at Jena.

Very soon after the founding of the gardens at Padua and Pisa, plants other than those of strietly medicinal value were introduced into the physic gardens. This was due to the revival of interest in the plant world which took place about the middle of the sixteenth century and to the desire for travelling and interest in eollecting which then sprang up. Conrad Gesner, writing in 1561 in the "Horti Germaniae," mentions that in botanic gardens not only medieinal herbs were eultivated but also other plants, especially rare ones, for the purpose of observing and admiring nature:

"Hortorum alii vulgares sunt, utilitatis tantum gratia confiti : in quibus olera, legumina, vites, fructus qui edendo sint, \& gramen, usum homini aut peeori praebent. Alii medicinales, ut Medicorum \& Pharmacopolarum: in quibus non hortenses tantum stirpes, sed etiam sylvestres omnis generis, \& peregrinae quoque coluntur, propter remedia quae ex ipsis earúmve partibus homini fiunt. Alii similes istis, sed magis varii, in quibus non solium plantae remediis nobiles, sed aliae etiam quae uis rariores praesertim coluntur, propter admirationem \& contenplationem naturae."

John Ray visited both Padua and Pisa early in 1664; referring to the garden at Padua, he says: "Here is a public Physick garden, well stored with simples but more noted for its prefeets, men eminent for their skill in Botanies." The Pisan garden at this time would not appear to have been in a very flourishing condition since Ray merely remarks, "The

\footnotetext{
${ }^{1}$ Gesner, Conrad. Horti Germaniae p. 237 verso. Strasburg, 1561.
} 
Physick Garden at our being there but meanly stored with simples."'

In partienlar, Gesner² alludes to several gardens at Padua and mentions the one under the charge of Anguillara, which was no doubt the Botanic Garden, as having a fine collection of plants with representatives from Syria, Crete and other distant places. He refers in the first place to the Garden of Caspar à Gabrielis "vir inter nobiles Patavinos longe nobilissimus," and then to "Priulanus hortus magnificus," which was under Aloisius Anguillara (Romanus). Gesner's account is as follows:

"Ibidem Priulanus hortus magnificus, plantis variis \& raris e Syria etiam accersitis admirationi est. Omnes vero omnium, ni fallor, hortorum magnificentia simul, \& stirpium in eo variarum omnis generis, e Creta etiam \& aliunde peregrinarum, numero laudes facile vincit publicus ille Patavii in medicorum gratiam inclyti Senatus Veneti liberalitate institutus hortus, cui hoc tempore Aloisius Anguillara Romanus, vir in stirpium historia nostro seculo excreitatissimus atque peritissimus omnium, magna cum laude praeest."

According to Saccardo, ${ }^{3}$ Lnigi Squalermo (detto Anguillara) was the first prefect "dell 'orto padovano ed ostensori dei semplici" from 1546 to 1561.

From this time onwards, no doubt, the tendency was to grow as many plants as possible, and a healthy rivalry commenced between the various botanical establishments as to who could show the greatest number of different species in cultivation.

${ }^{1}$ Ray, J. Travels through the Low Countries 1: p. 182. 1738. [2nd ed.] Ray mentions the following eminent men at Padua: Aloysius Mundella, Aloysius Anguillara, Melehior Guilandinus, Jacobus Antonius Cortusus, Prosper Alpinus, Joannes Veslingius. Garden :

Saccardo, loc. cit. p. 7, gives the following list of Prefects of the Paduan

1546-1561 Luigi Squalermo (detto Anguillara).

1561-1589 Melehiore Guilandino.

1590-1603 Giacom' Antonio Cortuso.

1603-1616 Prospero Alpini (o Alpino).

1610-1631 Giovanni Prevozio (Prevot).

1631 Giovanni Rhodio, iosto rinunciatario.

1631-1637 Alpino Alpini.

1638-1649 Giovanni Veslingio.

${ }^{2}$ Gesner, C. De IIortis Italiae. Loc. cit. p. 239 verso.

Loc. cit. p. 7 . 
In the botanic garden at Paris, for example, in the year 1636, there were about 1,800 species under cnltivation and the number had risen in 1640 to 2,360 , and in 1665 to as many as 4,000 species.

With the interest aroused in the collection and cultivation of plants came also the interest in their description and illustration, and many bulky and costly works were produced to illustrate the plants grown in botanic gardens.

In Great Britain the foundation of the botanic gardens at Oxford, Chelsea, and Edinburgh, was preceded by the establishment of several interesting private gardens devoted to the cultivation of medicinal herbs and plants of botanical interest, catalogues of which were published. The Rev. William Turner (1510-1568), who has been called the "Father of English Botany," had a garden somewhere at Kew and afterwards a renowned garden at Wells, when he was Dean of the Cathedral. Then there was the noted physic garden of John Gerard (1545-1612) in Holborn, at that time the most fashionable district in London, the catalogue of which-published in 1596-enumerates 1,030 plants and is of interest as being the first complete catalogue ever published of the contents of a single garden. His 'Herball,' published in 1597, was not his own work, but was simply a translation by a certain Dr. Priest of the 'Stirpium Historiae Pemptades' of Dodoens, which Gerard adopted and published as his own. On the title page of the edition of 1597, a garden is figured which has been generally considered to represent Gerard's own garden in Holborn, but as Sir Frank Crisp ${ }^{1}$ points ont, he obviously borrowed his illustration from an engraving by A. Collaert, representing a garden of A. D. 1590, in April, much in the same unscrupulous manner as he borrowed his text.

Among other early private physic gardens of interest in connection with the history of such institutions in England may be mentioned the garden of Thomas Johnson, M.D., the apothecary who had a garden on Snow Hill, in 1633-lie it

${ }^{1}$ Guide for the use of visitors to Friar Park, Henley-on-Thames, Pt. Il. Illustrations of some mediaeval gardens p. 87.1914.

The illustration reproduced by Gerard is to be found on the title page of Tabernaenontanus, J. T. Kreuterbuch. [eds. of 1664 and 1687.] 
was who brought out the improved and enlarged edition of Gerard's 'Herball' in 1638. The garden of John Parkinson (1567-1650), apothecary to James I, and King's Herbalist in Long Acre, and that of John Tradescant (died 1638) the elder, at Lambeth, are also worthy of particular mention.

John Tradescant, his father and his son were all of them botanists, collectors, and travellers. Tradeseant the elder, who was gardener to various noblemen and also to Queen Elizabeth, was appointed Gardener to Charles I and founded a garden at Lambeth. This garden, after that of Gerard, was probably the most important early botanic or physic garden in England, and a catalogue of the plants therein was published in the 'Museum Tradescantianum' by his son in 1656 . In addition to the garden, the Museum is worthy of notice in passing, since the curiosities it eontained were bequeathed by the younger Tradescant to Mr. Ashmole, and formed the nucleus of the collection in the Ashmolean Museum at Oxford. ${ }^{1}$

Parkinson was created King's Herbarist, "Botanicus regius primarius," by Charles I. He was a horticulturist rather than a pure botanist, and his well-known book on garden plants, 'Paradisi in sole Paradisus Terrestris,' published in 1629, probably did much to stimulate interest in the enltivation of new and rare ornamental plants. Parkinson it was who had the boldness to depict the Garden of Eden on the title page of his 'Paradisus,' and includes among other remarkable products, the "Vegetable Lamb," a pineapple, and an opuntia, the two latter plants being, as far as we are aware, unknown in the Eastern Hemisphere before the discovery of America.

Reference need only be made in passing to garden illustrations from 1580 and onwards, and to such works as the 'Hortus Floridus' of Crispian de Passe, published in Holland in 1614, and to the numerous herbals that were being produced to show the great strides that had been made in horticulture and botany in Elizabethan and early Stuart times.

The establishment of a botanie garden in Oxford in the year 1621, the nineteenth year of the reign of James $\mathrm{I}$, is an

${ }^{2}$ See Johnson, G. W. History of English gardening p. 98. London, 1829. 
important landmark in the history of botanical progress in England and follows the lead already given by the founding of university botanic gardens on the Continent.

Like them, it was "primarily founded for" a Nursery of Simples, and that a professor of Botanicey should read there and shew the use and virtue of them to his auditors."

The founding of the Oxford Garden ${ }^{1}$ was due to the munificence of Henry, Lord Danvers, Earl of Danby, who acquired the lease of five acres of meadow land by the River Cherwell, near Magdalen College, and arranged that the University should lease the ground from the College, to whom it belonged. The land was considerably raised to prevent flooding, at great expense, and was smirounded by a wall which was completed about 1632 .

Access to the Garden was by means of the Danby gateway, the foundation stone of which was laid with all fitting ceremony on St. James' Day, 1621, by the Vice-Chancellor of the University. ${ }^{2}$ The following is taken from Vines and Druce : ${ }^{3}$

\section{"Botanic Lectures.}

"The next Lecture that must be mentioned is that of Botanicey: but before I speak anything of its institution and settlement, I think it convenient that somewhat should be said of the Physic Garden, because 'twas primarily founded for a Nursery of Simples, and that a Professor of Botanicey should read there, and shew the use and virtue of them to his Auditors.

"Henry Lord Danvers therefore, Baron of Dauntsey in the County of Wilts and Earl of Danby in Yorkshire, sometime a Gent. Com. of Christ Church, being minded to become a Benefactor to the University, thought that his money could not be better laid out than to begin and finish a place whereby learning, especially the Faculty of Medicine, might be improved. At length selecting a place without the East Gate of Oxford, near the river Cherwell, which was then meadow ground, and

${ }^{2}$ Daubeny, C. The Oxford Botanic Garden, popular guide. Oxford, 1850; Günther, R. T. Oxford Gardens. Oxford, 1912; Vines, S. H., and Druee, G. C. An aeeount of the Morisonian Herbarium, etc. [Introduetion.] Oxford, 1914.

'The date of the founding of the Garden has usually been ineorrectly given as 1632, the year of the completion of the gateway, and in the account given by Wood of the foundation of the Garden there is a mistake of 1622 for 1621 , bnt in their interesting epitome of the history of the garden, Vines and Druce show clearly that 1621 is the correct date when the ground was handed over and delegates were appointed.

Loc. cit. pp. IX-X. 
had in ancient times been a Cemitery for the Jews of Oxon, gavo to the University $£ 250$ to make a purchase of it. Upon the receipt of it they bought out the present possessor thereof, Mar. 27, $19 \mathrm{Jac}$. Dom. 1622; and not long after the University took a lease of the said ground from Magdaten College (for to them it did belong) in their own name July 28 following, by paying yearly for it $40 \mathrm{~s}$. Afterward much soil being conveyed thither for the raising of the ground to prevent the overflowing of the waters, the first stone of the fabric was laid on the day of St. James the Apostle (July 25) an. 1622, after this manner: About two of the clock in the afternoon, the Vicechancellor with certain Heads, Doctors, and both the Proctors, went solemnly from St. Mary's Church to that place; where being settled, Mr. Edward Dawson, a Physician of Broadgates, spoke an elegant Oration; which being done, Dr. Clayton, the King's Professor of Medicine, spake another. Afterward the Vicechancellor laid the first stone with the offering of money thereon, according to the ancient custom; then several Doctors and both the Proctors; which being done, the Vicechancellor concluded with a brief Oration.

"Afterward the said Earl proceeding in building and encompassing it with a stately free-stone wall; which being almost finished, set up in front thereof, next to the East Bridge, a comely Gatehouse of polisht stone; on which for the perpetuation of his name, he caused this Inscription to be engraven on the out and inside thereof:

\section{GLORTAE DEI OPT. IIAX. HONORI CAROLI REGIS \\ IN USUM ACAD. et REIPUB. \\ HENRICUS COMES DANBY D. D. MDCXXXII.}

In the year 1633 all the wall being finisht, and soon after the floor raised, which cost the Earl $£ 5,000$ and more, he caused to be planted therein diver's simples for the advancement of the Faculty of Medicine. All which and several hundred more may now compare with any in the kingdom or elsewhere."

An interesting plan of the Garden by Loggan, made in 1675, shows four main enclosures within the boundary wall, each containing four series of geometrically arranged beds according to the formal arrangements then in vogue.

'Thomas Baskerville' gives the following description of the early condition of the Garden (about 1670-1700) :

"Amongst ye severall famous structures \& curiosities wherewith ye flourishing University of Oxford is enriched, that of ye Publick Physick Garden deserves not ye last place, being a

${ }^{2}$ Account of Oxford Collectanea (c. 1670-1700). 
matter of great use \& ornament, prouving serviceable not only to all Physitians, Apothecaryes, and those who are more immediately concerned in the practice of Physick, but to persons of all qualities seruing to help ye diseased and for ye delight \& pleasure of those of perfect health, containing therein 3,000 seucrall sorts of plants for ye honor of our nation and Universitie and service of ye Commonwealth."

A further interesting piece of information given by Baskerville is as follows:

"Anno 1670. Here was built by the Income of the money given by the ffounder a fair greenhouse or Conservatory to preserve tender plants and trees from the Injury of hard winter."

This conservatory covered with a roof of stone slates is shown in Loggan's plan and was of sufficient solidity to be transformed early in the eighteenth century into the herbarium, library, and professorial residence, but it was subsequently demolished.

The conservatory was heated in severc weather by means of a four-wheeled fire-basket, or wagon filled with burning charcoal, which was drawn backwards and forwards along the path by a gardener. ${ }^{1}$

Similar conservatories, or orangeries, were common in English gardens, and the building now used as a Museum (No. III) at Kew, was erected as an orangery in 1760 .

The first wooden greenhouses ever made were those erected at Oxford, in 1734, on either side of the Danby Gate. ${ }^{2}$

Although the Garden was founded in 1621, it appears that some twenty year's elapsed before Jacob Bobart was appointed the first gardener, owing probably to delays caused in preparing the site. Under his supervision the Garden attained a considerable reputation and was visited by many distinguished people, including Evelyn and Pepys. Bobart's catalogue of the plants cultivated, published in 1648, enumerates 1,600 plants, 600 of which were British, and many Canadian; it may be taken as evidence of his successful management of the Garden.

'See Gardeners' Chronicle N. S. 23:732. f. 163. 1885. The figure is reproduced in Giinther, R. T. Oxford Gardens p. 92. Oxford and London, 1912.

${ }^{2}$ See engraving in Oxford Almanac, 1766; reproduced in Günther, loc. cit., plate facing p. 153 . 
Owing to the outbreak of the Civil Wars and the death of the Earl of Danby, in 1644, his intention to provide the University with a Professor of Botany as well as with a physic garden and a gardener, was long delayed, and the first professor, in the person of Dr. Robert Morison, was not elected to fill the office until December 16, 1669. Morison's first lecture was given in the Medicine School on September 2, 1670, and on September 5, he "translated himself to the Physic Garden where he read in the middle of it (with a Table before him) on herbs and plants for five weeks space, not without a considerable Auditory."'1

Space does not permit us to follow the fortunes of the Oxford Garden or to make mention of the many distinguished professors associated with it since its foundation, but it is of interest to remember that Sir Joseph Banks was a student at Christchurch, from 1760 to 1763, in the days of Sibthorp's professorship, a time when no lectures on botany were given and the subject was much neglected in the University.

Banks was so keenly interested in botany that he applied to Sibthorp for permission to procure a qualified lecturer to be paid entirely by the students. This request being acceded to and a sufficient number of students having been obtained, Banks went to Cambridge and secured the services of a Mr. Lyons, a botanist and astronomer, for the purpose. ${ }^{2}$ The assistance rendered by the sister university in the botanical education of one who was to achieve such great things for the science and to have so large a share in directing the fortunes of the Royal Gardens at Kew, is worthy of more particular notice since botany was not officially recognized in Cambridge until 1724, when a professor was appointed, and there was no botanic garden there until the year 1762 .

The Botanic Garden at Edinburgh, which now claims attention, has had a somewhat involved history, as the present Royal Botanic Garden is the sixth and only remaining botanic garden in the Scottish capital, though in the early years of

${ }^{1}$ Vines, S. If., and Druce, G. C. loc. cit., p. XXIV.

'Anonymous, Sir Joseph Banks and the Royal Society p. 62. London, 1844. 
the eighteenth century there were three distinct gardens in Edinburgh.

The original Edinburgh Garden was founded by Sir Robert Sibbald and Sir Andrew Balfour, physicians, for the cultivation of medicinal plants in order "to safeguard the Practitioner against the Herbalist and to enable him to have a correct knowledge of the plants which were the source of the drugs he himself would have to compound."1

For this purpose they acquired the lease of a small area of ground near Holyrood, and James Sutherland was secured to look after it and instruct the apprentices and lieges in botany. Such success attended the venture that a piece of the Royal Flower Garden at Holyrood was assigned to the cultivation of medicinal plants and this with the title of Physic Garden became the Royal Botanic Garden in Scotland.

In 1767 the same physicians acquired from the Town Council of Edinburgh a lease of the Garden of Trinity Hospital and adjacent ground-a site now partly occupied by the Waverley Station-and Sutherland was appointed to lecture on botany as Professor in the Town's College, now the University, and to be in charge of this new Physic or Town's Botanic Garden. Then in 1702 another botanic garden was established by the University-the College Garden-of which Sutherland was also placed in charge. The distance of the two existing gardens being too great from the University, Sutherland resigned the care of the Town's Garden and College Garden in 1706, but remained King's Botanist, retaining the Keepership of the Royal Botanic Garden, and the Town Council appointed a professor to take charge of the Town and College Gardens. There were thus two rival botanical schools with their gardens in Edinburgh, and it was not until the year 1739 that the rivalry was terminated by the appointment of Dr. Charles Alston, the then Keeper of the Royal Botanic Garden, to the University Chair-a combination which holds to the present day by consent of the Crown and the University.

1 Balfour, I. Bailey, History of the Royal Botanic Garden, Edinburgh. Notes of the Roy. Bot. Gard., Edinburgh 4: 1904. IIistoric Notice. pp. v-viii. 
Between the years 1760 and 1786 a new site was found for a botanic garden and the other gardens were abandoned. This new garden, formed during John Hope's keepership, eventually became unsuitable owing to the growth of the town, and the present site (twenty-seven acres) was selected about 1820 , during the keepership of Professor Graham.

The Edinburgh Garden, through the University, still retains its connection with the Medical School, and the instruction of the medical student is one of the functions of the Professor and his staff. With its fine collections of living plants, its herbarium, library, laboratories, and remarkable series of specimens in the museums, the Edinburgh institution may well serve as an example of the ideal botanic garden.

The Chelsea Physic Garden, ${ }^{1}$ which next claims attention, was founded as the Garden of the Society of Apothecaries ${ }^{2}$ in London in the year 1673. The earlier garden of the Society had been at Westminster, but this had no river frontage, and the ground at Chelsea was leased from Charles Cheyne, in 1673 , as a convenient spot for building a barge house for their processional barge in which they attended city functions, as was customary for city companies.

In 1676 the plants at Westminster were moved to the Chelsea Garden, which had already been suitably enclosed with a wall. The freehold of the Manor of Chelsea, including the Physic Garden, was purchased in 1712 by Dr. (afterwards Sir Hans) Sloane, who in the year 1722 conveyed the Garden by deed to the Society of Apothecaries. The conveyance was made "to the end that the said garden might at all times thereafter be continued as a Physick Garden, and

${ }^{1}$ Fiek, H., and Semple, R. H. Memoirs of the Botanic Garden at Chelsea. London, 1878.

${ }^{2}$ The Socicty of Apothecaries itself was formed in 1617 "that the ignorance and rashness of presumptuous Empirics and unexpert men might be restrained, whereby many discommodities, inconreniences and perils do daily arise to rude and incrcdulous people." See Blunt, R. Cheyne WValk and thereahout p. 99. London, 1914.

Ccrtain continental botanic gardens, such as the ancient garden at Salzburg were founded in connection with local pharmaceutical schools and have had no connection with any university. 
for the better encouraging and enabling the said Society to support the charge thereof, for the manifestation of the power, wisdom, and glory of God in the works of the creation, and that their Apprentices and others might better distinguish good and useful plants from those that bore resemblance to them, and yet were hurtful and other the like good purposes."1

The utilization of the Garden for the sole purpose of growing medicinal plants to be converted into drugs for the Society's use was prohibited by Sir Hans Sloane's deed of gift, and he definitely encouraged the science of botany by making it a condition that fifty specimens of distinct plants, well dried and preserved, which grew in their garden that same year, with their names and reputed names, were to be delivered yearly to the President and Fellows of the Royal Society of London, "until the number of two thousand had been attained." He also enjoined that the plants so presented in each year were to be specifically different from those presented in every former year; and this injunction was more than faithfully carried out by the Society. ${ }^{2}$

The Garden achicved some notoriety in having been the first garden in England where the Cedar of Lebanon was planted; the final survivor of the four placed there in 1683 was only removed in the year 1904 .

John Evelyn, who visited the Garden in 1685, was impressed by the heating arrangement of the greenhouses, then quite an innovation. "What was very ingenious," he remarks in his diary, "was the subterranean heate conveyed by a stove under the conservatory, which was all vaulted with bricks, so as he ${ }^{3}$ has the doores and windows open in the hardest frosts, secluding only the snow." An arrangement far more efficient and useful than the remarkable open fire-baskets formerly in use at Oxford.

${ }^{1}$ Perrédès, P. E. F. London Botanie Gardens. Wellcome Chemical Research Laboratories, London, Publ. 62: p. 57. London, 1906 (transferred from the present to the past tense).

${ }^{2}$ Johnson, G. W. History of English gardening p. 150. London, 1829.

${ }^{8} \mathrm{John}$ Watts, appointed gardener in 1680. 
The appointment of Philip Miller, ${ }^{1}$ in 1723, as Head Gardener, is an important event in the history of the Garden, both for the value of his services to the Garden itself and for his widespread influence on botany and horticulture.

At the time of Miller's appointment, exotic plants were pouring in from every elime under the patronage of a general taste for their acquisition. Hothouses were multiplying and their inhabitants accumulating to a hitherto unheard-of extent, and a man of Miller's practical skill and botanical knowledge was needed not only to demonstrate his skill, but also to impart his knowledge for the use of others. From his 'Dictionary' it can be seen that many plants were grown and flowered at Chelsea for the first time under cultivation.

William Aiton (1731-1793), the first Curator of the Royal Gardens at Kew, was a pupil under Miller at Chelsea, nor must Nathaniel Bagshaw Ward, Examiner to the Society of Apotheearies from 1836 to 1854, the inventor of Wardian cases, be forgotten. His invention made possible the introduction of the tea plant to India by Robert Fortune (Curator of the Chelsea Garden, 1846-1848), of Cinchona from South America to Kew by Markham, and thence to India, and of many other valuable produets to botanic gardens which have subsequently been disseminated for the use of mankind. Not the least useful of the activities of the Chelsea Physie Garden were the herborizing exeursions around London, under the charge of the Demonstrator of Plants, which were maintained for some two hundred years. The Pliysie Garden has suffered many vicissitudes in the course of its existence, and towards the end of the last century almost ceased to exist, but fortunately a new arrangement for its maintenance was made in $1899 .^{2}$ Reorganized under the new scheme and with its modern greenhouses and laboratory, the Chelsea Garden has entered on a sphere of usefulness in connection with the teaching of botany and the provision of material and opportunity

'Charles Miller, son of Philip (who had aided in the selection of the site), was made first Curator of the original Cambridge University Botanical Garden founded in 1762 .

${ }^{2}$ The Chelsea Physic Garden. First Report of Committee of Management, 1905 , with plan of the Garden in 1753. 
for botanical investigation as great if not greater than at any time in the past.

The origin of the Royal Botanic Gardens, Kew, was due to the interest in botany displayed by Princess Augusta, Princess Dowager of Wales, under the guidance of Lord Bute, an enthusiastic botanist; and a piece of the Royal Garden attached to Kew House was set apart in $\mathbf{1 7 6 0}$ for the purpose of forming a physic garden.

"The space allotted consisted originally of nine acres, enclosed by walls (the ornamental building now standing, called the Temple of the Sun, being then nearly the centre of the Garden), which was laid out and scientifically planted in two divisions, one containing a collection of herbaceous plants, arranged according to the Limnean system, then in its infancy, but with which Aiton had become well acquainted while serving under Miller. This division was called the Physic Garden.

"The second division was called the Arboretum, containing all the then known introduced hardy trees and shrubs scientifically arranged. Within the area were several Glass houses, and in 1761 a large hothouse, 110 feet long, was erected by Sir Wm. Chambers . . in after years known as the Great Stove. In the same year an Orangery, 130 feet long, was also erected."1

No doubt several of the old and interesting trees now standing near the Temple of the Sun were planted in Princess Augusta's arboretum soon after the foundation of the Garden.

William Aiton was placed in charge of the Garden under the direction of Lord Bnte, and was Chief Gardener from 1759 to 1793. Sir W. Chambers, the designer of the Pagoda and most of the Temples still to be seen in Kew, gives the following account of Princess Augusta's Physic Garden:

"The Physic or exotic garden was not begun before the year 1760 ; so that it cannot possibly be yet in perfection; but from the great botanical learning of him who is the principal man-

${ }^{1}$ Smith, John. Records of the Royal Botanic Gardens, Kew. p. V. 1880. See also Kew Bull. Misc. Inf. 1891:289-294. 1891.

The Great Stove stood near the Temple of the Sun and was removed in 1861. Its site is marked by an old wistaria, trained on an iron eage whieh grew upon its walls. The method of ventilating the house was designed by William Hales, the physiologist, who described his method in a letter to Linnaeus written in 1758. The method is in use at kew to-day and was devised independently by Sir W. T. Thiselton-Dyer.

The Ornngery is now Museum No. III. 
ager and the assiduity with which all curious productions are collected from every part of the globe without any regard to expense, it may be concluded that in a few years this will be the amplest and best collection of curious plants in Europe."1

With the death of Princess Augusta in 1772, George III inherited the Kew property and united the gardens of Kew House with those lying contiguously, which formed the gardens of the Palace of Richmoud, and so produced the extensive domain now occupied by the Royal Botanic Gardens. To the great benefit of Kew, George III chose Sir Joseph Banks as his botanical adviser, and for forty-eight years Sir Joseph directed the affairs of the Gardens. During his term of office the practice of sending out collectors was established, a practice fraught with discoveries of wide-spread interest and value for horticulture and botany. Of the many Kew collectors ${ }^{2}$ it is well to mention in particular the following: Francis Masson, the famous collector of Cape plants; David Nelson, assistant botanist on Cook's third voyage, who subsequently died from exposure after the mutiny of the Bounty; Archibald Menzies, who travelled in Australia and Chili and introduced Araucaria imbricata; William Ker, the collector in China, who in 1812 became Superiutendent of the Royal Botanic Garden, Ceylon; and Allan Cunningham, whose travels took him to Brazil, the Cape, Australia, Tasmania, New Zealand and Norfolk Island. Cunningham returned to Australia, in 1836, to fill the post of Superintendent of the Botanic Garden at Sydney.

The days of Sir Joseph Banks were indeed the Golden Age of Kew, and under his direction the Royal Gardens became a center of botanical exploration and lorticultural experiment unparalleled before or since. The well-known lines of Erasmus Darwin ${ }^{3}$ refer to the Kew of Sir Joseph Banks' day, enriched by the labors of her collectors:

${ }^{1}$ Chambers, Sir W. Plans, elevations, sections and perspective views of the gardens and buildings at Kew in Surrey, the seat of Her Royal Highness, the Princess Dowager of Wales p. 3. Brentford, 1765?

${ }^{2}$ For the complete list of Kew collectors, see Kew Bull. Misc. Inf. 1891: 295-311. 1891 .

The Botanic Garden. 1791. 
"So sits enthroned, in vegetable pride,

Imperial Kew by Thames' glittering side;

Obedient sails from realms unfurrow'd bring

For her the unnam'd progeny of Spring;

Attendant Nymphs her dulcet mandates hear, And nurse in fostering arms the tender year; Plant the young bulb, inhume the living seed, Prop the weak stem, the erring tendril lead; Or fan in glass-built fanes the stranger flowers, With milder gales, and steep with warmer showers.

Delighted Thames through tropic umbrage glides, And flowers antaretic, bending o'er his tides;

Drinks the new tints, the sweets unknown inhales, And calls the sons of Science to his vales."

George III and Sir Joseph Banks both died in 1820, and for some twenty years the Royal Gardens gradually fell into a condition of sad neglect. In the early years of the reign of Queen Victoria, however, the Royal Gardens were restored to their proper position as the National Botanical Garden, thanks to the devoted labor's of the committee of which John Lindley and Sir Joseph Paxton were the distinguished member's, and Sir William Hooker was appointed Director of the Royal Botanic Gardens in 1841. Thence onwards, under Sir Joseph Hooker, and Sir William Thiselton-Dyer, the history of Kew has been one of steady progress and usefulness and the Royal Botanic Gardens have played a prominent part in connection with all matters of botanical enterprise in the British Colonies. ${ }^{1}$

${ }^{1}$ The establishment at Kew comprises: I. The Botanic Gardens and Arboretum (288 acres); II. The Herbarium and Library; III. The Musenms devoted to ( $\mathrm{i}$ and ii) dicotyledons and monocotyledons and their economic products, (iii) exotic timbers and conifers, (iv) British forestry, and (v) The North Gallery of paintings by Miss Marianne North; IV. The Jodrell Laboratory for scientific research; V. The Pathological Laboratory; VI. Director's Office.

The more important books dealing with the history of Kew and its collections are:

1. Aiton, IV. Hortus Kerrensis, 3 vols. London, 1789.

2. Aiton, W. T. Hortus Kewensis, 5 vols. London, 1810-13. [2nd ed.]

3. Scheer, F. Kew and its Gardens. Richmond, 1840.

4. Historical account of Kew to 1841. Kew Bull. Misc. Inf. 1891:279-327. 1891.

5. Royal Botanic Gardens, Kew, Reports on progress and condition, 1855-1882.

6. Perredès, P. E. F. London Botanie Gardens. Wellcome Research Laboratories, London, Publ. 62: 17-40. 1906.

7. Rean, W. J. The Royal Botanic Gardens, Kew. London, 1908.

8. Popular Official Guide to the Royal Botanic Gardens. Kew, 1912.

9. Kew Bull. Misc. Inf. 1887.

10. Kew Plant Lists and Mnseum Guides.

11. Smith, J. Records of the Royal Botanic Gardens, Kew. London, 1880. 
Kew, having no connection with any university or educational establishment, ${ }^{1}$ differs markedly in this respect from the botanic gardens to which allusion has been made. Her sphere of usefulness is largely concerned with the economic aspect of botany, and it is her aim and object to enconrage and assist, as far as possible, scientific botanists, travellers, merchants and manufacturers, in their varied botanical investigations.

Space does not permit of more than a brief mention being made of the new Berlin Garden at Dahlem and of many other important gardens on the Continent and in Great Britain and Ireland. The Berlin Botanic Garden ${ }^{2}$ was founded in 1679 in the heart of the city, and in 1801 it was reorganized and improved. The removal of the Garden to its present site at Dahlem was completed in 1909 . The new Garden with its geographical and ecological arrangements of the plants and the splendid Botanical Institute and Museums, now forms one of the finest schools of botany in the world. In her aims and objects she compares more closely to Kew than to any other botanic garden.

The following notes refer to other important gardens not specifically mentioned in the text:

The Upsala Garden (founded 1655-57) was injured by the great fire in 1702, and remained neglected until 1741. The restoration was begun by Rosen and energetically taken up by Linne. (See Swerderus, M.B. Botaniska Tragarden, Upsala, 1655-1807. Falun, 1877.) The Imperial Botanic Garden of Peter the Great, Petrograd (St. Petersburg), was founded in 1713 (see Kew Bull. Misc. Inf. 1913:243-252. 1913), and tbat of Vienna in 1754.

The Cambridge Botanic Garden was founded in 1762 by Richard Walker, D.D., formerly Vice-Nlaster of Trinity College. The Garden was transferred to its present site in 1846 and occupies about twenty acres. It is in close connection with the Botany School at Cambridge and provides abundance of material for research work and for the teaching purposes of the Botany School. The Garden is also fitted with a small laboratory. Some eighteen acres are available for extension.

${ }^{1}$ Lectures and demonstrations in chemistry and physics, general botany, systematic and geographical botany, economic botany, plant pathology and on soils and manurcs are given in the Gardens to the young gardeners at kew.

'See Urban, I. Geschichte des Königl. botanischen Gartens und des Königl. Herbariums zu Berlin, nebst einer Darstellung des augenblicklichen Zustandes dieser Institute. Festschr. naturwiss. 1. med. Staatsanst. Berlin, 1881.

Engler, A., and others. Der Kgl. bot. Garten und das Kgl. bot. MLuseum zu Dahlem. Berlin, 1909. 
The Royal Botanic Gardens, Glasnevin, Dublin, were founded in 1790, through the influence of Dr. Walter Wade and the Hon. Dublin Society, and in 1877 were transferred to the Science and Art Department. The Botanic Garden of Trinity College, Dublin, was established in 1806-08. (See Notes from the Botanical School of Trin. Coll., Dublin 1:p. 3. 1896.)

The garden at Breslau was fonnded in 1811. The Geneva Garden, founded in 1817, has recently been transferred to a new site. The Munich Garden was founded in 1822 (see Martins, Hort. Bot. R. Acad. Monacensis p. 5. 1825.) It is now one of the most interesting gardens on the Continent and forms an integral part of the new and magnificently equipped Botanical Institute.

The Glasgow Botanic Garden was established iu 1817, having been preceded by an earlier Physic Garden; in 1841 the garden was moved to its present site and now occupies about forty acres (see Sherry, C. The Glasgow Botanic Gardens. Glasgow, 1901).

The botanic gardens whose history has been sketched in the preceding pages can all trace back their origin to the herb gardens of mediaeval times and the physic gardens of the early universities. Their raison d'être, the growing of simples for the medical profession, has resulted in the exploration of the globe for the useful, the beautiful, and the curious in the vegetable kingdom. A few other botanic gardens, however, remain to be considered, whose origin must be traced to a different motive. These gardens lie within the tropics, and the desire to participate in the valuable trade in spices, then a monopoly of the Dutch, led to the establishment of gardens for the cultivation of various spices and other important economic plants during the latter part of the eighteenth century.

The credit of establishing economic gardens in the tropics belongs to Great Britain, and the experiment, started with the founding of the botanic garden in the Island of St. Vincent, in 1764, has been continued, at times somewhat intermittently, until at the present day a botanic garden or station is to be found in almost every British dependency and possession.

The lead given by Great Britain has been followed by other nations and several notable achievements have resulted. Foremost among these must be mentioned the Botanic Gardens at Buitenzorg, Java, ${ }^{1}$ probably the most complete and exten-

1 The complete institution at Buitenzorg, known as "Lands Plantentium," is divided into nine Departments: I. Herbarium and MIuseum; II. Botanical 
sive botanical establishment in the world. The garden was founded in 1817 at the suggestion of Reinwardt, ${ }^{1}$ and Dr. C. L. Blume was appointed the first Director when Reinwardt left Java to become Professor at Leiden. The first Curator, James Hooper, had been trained at the Royal Gardens, Kew. The valuable scientific resenrches in pure and applied botany carried out at Buitenzorg are too well known to require detailed description, and allusion need only be made to the important encouragement given to the cultivation of Cinchona, rubber, coffee, and other economic products in Java, through the medium of the Botanic Gardens.

The earliest tropical botanic garden appears to have been that founded in the West Indies at St. Vincent, in $1764 .^{2}$ A garden of about forty acres was established with Government House in the center, as a place where plants "useful in medicine and profitable as articles of commerce might be propagated and where nurseries of the valuable productions of Asia and other distant parts might be formed for the benefit of His Majesty's Colonies." Plants intended for the West Indies were lost owing to the mutiny of the Bounty in 1790 , but three years later Captain Bligh succeeded in landing a valuable consignment of plants from the Pacific, including the bread fruit, and a few years after, nutmegs, cloves, and other spice plants were introduced.

Until 1815 the Garden flourished, when interest was shifted to Trinidad, where a garden was formed in 1817, and many

Laboratories; III. Agricultural and Experimental Garden (151 acres) with laboratory for agricultural chemistry; IV. Pharmacologieal Laboratory; V. Botanic Garden (145 acres), Mountain Garden $(77$ acres and 700 acres virgin forest), and Laboratory; VI. Office, Library, and Photographie Laboratory; V11. Forest Flora collections; V1II. Laboratory for the study of Deli tobaceo; IX. Coffee Experiment Station (the two last are partly private institutions).

${ }^{1}$ It is possible that the original idea of founding a botanic garden at Buitenzorg was made by Sir Stamford Raftles, when Governor of Java, during the few years (1811-17) that Java was a British possession. Near the entrance there is a small monument to the memory of Lady Raffles, who died in Java during the British occupation of the island.

Guilding, Rev. Lansdown. An account of the botanical garden in the island of St. Vincent. Glasgow, 1825. See also Kew Bull. Misc. Inf, 1892: 92-104. 1892 . 
of the plants were removed thence from St. Vincent. The St. Vincent Garden was restored in 1890 and now, fortunately, there is a botanic garden or station in every West Indian island of importance. These serve as centers for the distribution of economic plants and of scientific information, and have also become gardens of peculiar charm for the refreshment and recreation of the inhabitants.

The gardens of the East, however, are preëminent among tropical botanic gardens owing to the vastness of the territory over which they exercise their influence. Foremost among these, after Buitenzorg, is the Calcutta Botanic Garden, founded in 1786 on the suggestion of Lieut. Col. Robert Kyd.

This garden was intended to be the source of botanical information for the possessions of the East India Company, and also the center to which exotic plants of economic interest could be imported for experimental cultivation and thence distributed. ${ }^{1}$

It was hoped at first that the spices which rendered the trade of the East India Company with the Moluceas, etc., so lucrative, might be cultivated in Bengal, and Kyd's earliest efforts were directed to the introduction of cloves, nutmegs, cinnamon, and pepper vines, but the climate of northern India proved unsuitable. Much was attempted and, despite numerous failures, much accomplished in the way of new introductions in the early days, the failures possibly being as important as successes since it was soon evident what could or could not be grown in Bengal. The Calcutta Gardens, however, despite the failure in their original intention, have under their distinguished superintendents achieved notable results. The introduction of tea to India-one of Kyd's original ideaswas mainly carried out through the instrumentality of the Gardens, and potato growing, the introduction of mahogany, jute, sugar-cane, and the improvement of Indian cotton cultivation, may be counted among its many benefits to the people of India.

${ }^{1}$ King, George. Guide to the Royal Botanic Garden, Calcutta. 1895. 
But most important of all was the part played by the Garden in the introduction of Cinchona ${ }^{1}$ from South America to India with the coöperation of $\mathrm{Kew}$, and the subsequent cultivation of Peruvian bark in the Sikkim Himalaya. The Calcutta Garden in this particular has retained the ancient connection of botanic gardens with medicine perhaps more than any other similar institution. The cultivation of the quinineyielding cinchonas has been carried to such a successful issue in the plantation and factory at Sikkim under the superintendents of the Garden, notably Sir George King, that government hospitals and dispensaries have for years been supplied from this source with all the quinine required for them; while 5 -grain doses of the same drug can be purchased for a pice each (equal to about $\frac{1}{4}$ d. English) at every post-office in the Province. ${ }^{2}$

Associated with the Garden are the valuable herbarinm and the economic museums, the whole forming an institution capable of responding fully to the botanical requirements of the Indian Empire.

The history of botanic gardens would be incomplete without reference being made to the foundation of such institutions in Malaya and Ceylon. At Penang ${ }^{3}$ the Hon. East India Company decided to start spice gardens with a view of breaking down the Dutch monopoly. Living plants of nutmegs and cloves were collected in the Moluccas in 1796, and the first nutmegs were produced in Penang in 1801.

The Gardens, however, were destroyed ${ }^{4}$ in 1805 , and refounded in 1822 at the instance of Sir Stamford Raffles. He it was who founded the Singapore Gardens in 1823, and intro-

1 See Markham, Sir C. R. Peruvian Bark. London, 1880.

${ }^{2}$ Guide to Royal Botanic Garden, Calcutta p. 6. 1902. [Revised ed.]

"Ridley, H. N. The abolition of the Botanic Gardens of Penang. Agr. Bull. Straits and Fed. Malay States 9: p. 97. 1910.

1 Ibid. p. 104.

First Penang garden

Second Penang garden

Third Penang garden

First Singapore garden

Second Singapore garden

$\begin{array}{lc}\text { founded } & \text { abolished } \\ 1800 & 1805 \\ 1822 & 1826 \\ 1884 & 1910 \\ 1823 & 1829 \\ 1878 \text { and still existing. }\end{array}$


duced nutmegs, cloves, and cacao, but the Garden was unfortunately abolished in 1829 .

The botanical enterprise of this remarkable man in Java, Malaya, and Sumatra, deserves an honorable place in our botanical history, and no more fitting memorial of his genius conld be found than the present beantiful garden at Singapore, founded in 1878, which has so ably upheld the best traditions of the founder of the original garden.

The first botanic garden established in $\mathrm{Ceylon}^{1}$ was created by the Dutch on Slave Island, near Colombo, but this was neglected when the island passed into the possession of Britain, and it was not until 1810, when Sir Joseph Banks suggested a site, that a new garden was established, also on Slave Island at a place still known as Kew. William Ker was transferred from Canton, in 1812, and appointed superintendent. The Garden was not a success, owing to its situation, and in 1821, during the superintendence of Alexander Moonwho had been sent out by Banks-the Garden was transferred to Peradeniya. In its new site its history has been a record of prosperity, and its usefulness has been considerably increased by the formation of additional gardens in different parts of the island suitable to the varied climatic conditions of the country.

The scientific researches in pure and applied botany, in tropical mycology and chemistry, and the cultural experiments which have been carried out in the Gardens and laboratory in Ceylon have thoroughly justified the existence of the institution at Peradeniya, and prove, if proof were needed, the inestimable value of scientific botanical establishments in the tropics.

The colonizing of Australia soon led to the foundation of botanic gardens, and those at Sydney ${ }^{2}$ have the honor of being the first to be founded in the Australian Continent.

1 Trimen, Henry. Hand guide to the Royal Botanic Gardens, Peradeniya. Colomho, 1885.

${ }^{2}$ Sydney Botanic Gardens. Kew Bull. Misc. Inf. 1906: 205-218. 1906.

Maiden, J. H. Presidential address to the Royal Society of New South Wales, 1912. Roy. Soc. N. S. Wales, Jour. and Proc. 46: 1-73. 1912. [See p. 49.] 
These Gardens occupy the site of the Government Garden established in 1788, and here the first exotic plants were installed in the same year. Owing to the great demand for New Holland plants, due largely to the interest taken in them by Sir Joseph Banks, a vigorous exchange in plants soon grew up between the Sydney Gardens and the outside world, to the great profit of the institution, which appears to have been definitely founded as a botanic garden in the year 1816 .

Sydney is now fully equipped for botanical work with its renowned Botanic Gardens, its university department of botany, and museum.

Other well-furnished botanic gardens are to be found at Brisbane, Melbourne, Adelaide, Hobart, and Tasmania; at Melbourne and Adelaide their value is enhanced by association with the botanical departments of the universities.

Flourishing botanic gardens are also established in New Zealand, at Wellington, Dunedin, Napier and Christehurch. ${ }^{1}$

Before leaving the subject of botanic gardens in British Dominions, mention must be made of the foundation only last year (1913) of the National Botanic Garden of South Africa, at Kirstenbosch, ${ }^{2}$ which, though the most recent of such gardens, bids fair to take a place in the front rank of the botanic gardens of the world, both on account of the admirable nature of the site and the remarkable character of the South African flora. The predecessor of this garden was the Cape Town Botanic Garden, founded in 1848, which became the Municipal Garden of Cape Town in 1892, after a somewhat chequered career. ${ }^{3}$

The Municipal Gardens at Durban, Natal, established in 1853 as the Natal Botanic Garden, have played an important part in botanical enterprise in South Africa and at no time more than under the directorship of Dr. J. Medley Wood. It

1 The Botanic Gardens at Hong Kong with their herbarium form a raluable center for Asiatic hotany, nor must the Gardens at Tokyo and other important Japanese centers of botanical activity be omitted. Botanic gardens have been established also in Fiji, Seychelles, Mauritius, etc.

Kew Bull. Misc. Inf. 1913: pp. 309-314, and p. 373. 1913; Nature 93: 190-191. 1914.

- Kew Bull. Misc. Inf. 1892: 10-14. 1892. 
would be a most unfortunate oceurrenee should the activities of this important garden, small though it is, be in any way curtailed or its functions abrogated by the ehange in its administration or owing to the establishment of the new National Garden. ${ }^{1}$

In Ameriea, ${ }^{2}$ botanie gardens have been in existence since the year 1728, when John Bartram founded a botanical garden in Philadelphia. Thongh no longer a botanie garden, the plot of ground still remains and serves as an interesting landmark in the listory of North Ameriean botany. ${ }^{3}$ The foundation of the Elgin Botanie Garden by Dr. David Hosack, in 1801, was an important advanee and the Garden of some twenty acres was gradually stocked with a large and valuable eollection of plants. ${ }^{4}$ In 1810 it beeame the Botanic Garden of the State of New York and was subsequently granted to Columbia College. It has ceased to exist as a garden, but it will be always held in remembrance from its association with the work of its founder, of Amos Eaton, John Torrey, and Asa Gray.

The founding of the New York Botanieal Garden, as a result of the untiring energy of Dr. N. L. Britton and the Torrey Botanieal Club, may be regarded as a wortlyy monument to the memory of these pioneers in American botany. Furnished as it is with the Torrey Herbarinm, the value of which has been enhanced by vast acquisitions-including the Chapman and Meisner herbaria-, the library, museum, and laboratories, the New York Botanical Garden, in association with the Department of Botany of Columbia University, rivals

${ }^{2}$ Other botanic gardens and stations in Africa have been established in Uganda, in the British and French West African Colonies and at Victoria in the German Cameroons. In Algeria there is the fine old "Jardin d'essai" at Algiers.

${ }^{2}$ In Canada therc is a botanic garden at Ottawa in connection with the Agricultural Department, and a small garden at Montreal belonging to the botanical department of MeGill University.

${ }^{3}$ Bartram, through Peter Collinson, appears to have received seeds from Philip Miller of the Chelsea Physic Garden. See Wilbert, M. I. Some early botanical and herb gardens. Am. Jour. Phar. 80: 412-427. 1908. [See p. 416.]

- Hosack, David. A statement of facts rclative to the establishment and progress of the Elgin Botanic Garden, etc. New York, 1811.

Wilbert, M. I. Loc. cit. p. 423. 
in its completeness, if it does not already excel, any botanical institution in the old World. ${ }^{1}$

The Botanic Garden of Harvard University, which was founded in 1805, next claims attention. The garden itself is small, but in combination with the herbarium containing Gray's collection, the museums, library, and laboratories, it forms a botanical institution singularly complete and efficient.

With the Arnold Arboretum situated close at hand, Harvard has become a Mecca for botanists all the world over. The Arboretum, ${ }^{2}$ founded by Mr. James Arnold, covers at present about two hundred and twenty acres, and the collection of trees and shrubs brought together by the remarkable industry of Professor Sargent is unrivalled, and it stands to-day for one of the most interesting and valuable developments of the principles of a botanic garden. To Professor Sargent, as well as to such enlightened men as the de Vilmorins and the firm of Veitch, the gardening world also owes a great debt of gratitude for the introduction of countless new hardy plants for the enrichment of our gardens.

Important work is being performed by the United States Department of Agriculture, at Washington, in the introduction of new plants, nor should the part played by the herbarinm of the United States National Museum be forgotten in this connection. Allusion may also be made at this point to the Desert Laboratory at Tucson, and to the importance of the experimental work which is being undertaken in Hawaii, Cuba, and the Philippine Islands.

Other botanic gardens are those of the Michigan Agricultural College (1877), the University Botanic Garden at Berkeley, California, the Botanic Garden of the University of Pennsylvania at Philadelphia, of Smith College at Northampton, and the Buffalo Botanical Garden. These each and all are of recent foundation and have been established in response

${ }^{1}$ Britton, N. L. Botanical Gardens. N. Y. Bot. Gard., Bull. 1:62-77. 1897 ; Underwood, L. M. The department of botany and its relation to the New York Botanieal Garden. Columbia Univ. Quart. 4:278-292. 1903; Britton, N. L. Botanical Gardens. Bull. Torr. Bot. Club 23: 331-345. 1896. [See pp. 341-345.] See also Britton, N. L. Loc. cit. pp. $72-77$.

${ }^{2}$ Kew Bull. Misc. Inf. 1910: 261-269. 1910. 
to the need of such institutions for teaching and research in botany.

Finally there is the Missouri Botanical Garden, ${ }^{1}$ founded in 1889 by the munificence of Henry Shaw, in pious memory of whom this Twenty-fifth Anniversary Celebration is being held.

Founded on broad lines and generously endowed, the Garden has already established itself as one of the important botanic gardens of the world. With its herbarium, library, and laboratories, and the close relationship with the Shaw School of Botany of Washington University, the future of the Missouri Botanical Garden caunot fail to be one of everincreasing usefulness.

It is a matter of regret to all botanists that South America, so rich a storehouse of botanical treasures, should contain so few important botanic gardens. The magnificent Garden at Rio de Janeiro, ${ }^{2}$ founded in 1808 , the Botanic Gardens at Santiago in Chili, ${ }^{3}$ at Georgetown, British Guiana, and at Buenos Aires represent the measure of botanical enterprise in the continent.

The botanical possibilities at Rio de Janeiro are very great, and the Garden, in addition to its collection of living plants, possesses the herbarium of Martius, a library and laboratories. When the interest in botanical science becomes fully aroused in Brazil, a striking development of the botanic garden may be confidently expected.

\footnotetext{
${ }^{1}$ Trelease, W. The Missouri Botanical Garden. First annual report of the Director, for 1889. Mo. Bot. Gard., Rept. 1: p. 91. 1890.

Trelease, W. The Missouri Botanical Garden. Pop. Sci. Month. 62: 193221. 1903.

${ }^{3}$ Rodrigues, J. B. Hortus Fluminensis. Rio de Janeiro, 1894.

- Philippi, F. Vorgeschiclite des botanischen Gartens von Santiago. Gartenflora 31: 6-9. 1882. The date of the foundation of this garden is uncertain. herbarium and museum attaehed to the University. Sce also Plilippi, F. It contains a very interesting collection of plants and trces, and there is a good Memoria $i$ catalogo de las plantas cultivadas en el Jardin Botanico. Santiago de Chile, 1884.
} 


\section{Functions of Botanic Gardens}

The varied functions performed by botanic gardens in the course of their history have been indicated to some extent in the preceding pages, and the gradual change in function from that of the purely medicinal garden for the growing of simples to the fuller conception of the true botanic garden has been traced.

With the increase in knowledge and interest in botany, new plants were brought into cultivation from all sources and gardens threatened to be overwhelmed by unarranged masses of material. Classification, therefore, became a necessity and various systems began to be put forward in response to the demand. To these we cannot do more than make brief allusion. After the efforts of Caesalpino came Morison's system of classification, which did not receive general acceptance and was absorbed into that of Ray, and neither system found many adherents as regards the disposition of plants in the botanic gardens.

The two early systems which really dominated plant arrangement were those of Limnaeus and Jussieu, the latter finding acceptance in France, where the Linnaean system never became established.

To France, in consequence, we must look for the evolution of the natural system of classification, and, with its adoption, botanic gardens gradually developed into a means of providing a synoptical illustration of the whole vegetable kingdom.

It was in the Trianon gardens that Bernard and A. L. de Jussieu, towards the close of the eighteenth century, evolved the idea of grouping plants according to a system based on natural affinities, and the Trianon system was quickly imitated and elaborated in course of time by Gärtner, De Candolle, Robert Brown, and others.

With the revival of interest in plant collecting a new development took place, and plant geography came to the front as a basis of plant arrangement in botanic gardens. Thus collections were made to represent the floras of definite regions, such as that of New Holland or The Cape, and af- 
forded instructive and useful aids to the study of botany and plant distribution in particular.

These two tendencies in botanie garden arrangement hold good at the present day, and gardens may be found adhering to one or the other plan. Both systems have their merits, and where possible both may be followed with due regard to local conditions, but a slavish adherence to the one or to the other tends to court disaster and produce confusion rather than edification.

There is much to be said for the older ideas of separating "herbaceous plants" from "trees and shrubs," and for making an independent arrangement of the two classes, mainly on the ground of cultural requirements.

The natural system in plant houses, again, is almost certainly doomed to failure, and an arrangement on geographical or ecological lines must perforce be adopted.

How instruetive such an arrangement may be is shown by an arrangement of plants from alpine regions or by a collection of xerophytes representative of some particular desert area of the globe.

Plant physiology affords another basis for plant arrangement and perhaps is fruitful of greater educational value than almost any other system. It has the further advantage that it lends itself to adoption in the smaller garden where a complete conspectus of the vegetable kingdom is an impossibility.

In some botanic gardens on the Continent, particularly at Berlin, and to a smaller extent at Geneva and elsewhere, the flora of mountain regions is arranged with an attempt at actual verisimilitude as to soil conditions and altitudinal distribution of the zones of vegetation. The idea is an excellent one, lont its realization is liable to be far from perfect since the limiting factors of altitude and climate are absent and the plants of the mountain tops, deprived of their natural restrictions, tend to usurp more than their proper share of available space.

In whatever manner the main garden may be arranged, there should always be special portions set apart for certain well-marked plant types, such as alpine and rock plants, sue- 
culents, bulbous plants, halophytes, bog and water plants, and the like, and if possible there should also be a definite economic and medicinal garden. Plant houses should also be set apart for economic plants where such as are of definite medical and economic values may be studied in connection with their products displayed in the museums.

The exact determination of plants of economic value, especially in connection with the vegetation of the tropies, is a matter of such importance that the necessity of a wellfurnished herbarium and museum, in connection with a botanic garden of any pretension, needs no demonstration. With the aid of the herbarium, also the correct determination of all plants cultivated in a botanic garden should be ensured.

Just as necessary for the complete botanical establishment is the possession of a laboratory both for the examination and analysis of plants, and also for the study of such problems in mycology, plant physiology, plant hybridization, etc., as can be studied nowhere at greater advantage than in a botanic garden.

A somewhat unexpected exhibition in a botanic garden is an arrangement of fossil plants in the open, such as may be seen in the Breslau Botanic Garden, ${ }^{1}$ where the coal measure series of strata have been built up and characteristic fossil plants have been arranged to form a kind of fossil rockgarden. Such an exhibition as this in close connection with the collection of living plants, is probably of greater educational value than a similar display would be within the four walls of a museum and may be assumed to justify its formation.

How numerous are the possibilities of arrangement in the modern botanic garden has been fully realized by the enlightened botanists of the present day. The difficulty, however, which is being somewhat acutely felt in many institutions, is that of lack of space, not only for the vast numbers of new plants being introduced to cultivation - particularly from China-but also for new and important developments $\mathbf{J} 875$.

${ }^{1}$ Göppert, H. R. Der Königliche Garten der Universitait Breslau, Führer. 
made necessary by the progress of the science of botany both for teaching purposes and for research.

Experiments in plant breeding, for instance, which are a legitimate development of botanic garden research, demand an amount of space which many gar'dens arc unable to afford, and in the tropies in particular such work has had to be relegated to definite experiment stations. In England work of this character is being carried on mainly in connection with agricultural institutions and at the newly-founded John Innes Horticultural Institution at Merton, under the direction of Mr. Bateson, while in the United States such lines of inquiry are being pursued with laudatory vigor by the United States Department of Agriculture and by many other public and private institutions.

Another function of botanic gardens of first importance is the opportunity they afford for the training of men; and in work of this character Kew has probably played a larger share than any other garden. From Kew, in the course of her long history, her sons have gone out either as collectors or gardeners to bring home plants of interest and of economic value, or to take charge of the botanical establishments in the British Colonies and Dependencies. A glance at the Kew roll will also show how many of her young men are helping to propagate the art and science of horticulture in the United States of America.

With some of our larger institutions one of the most important functions in the past has been the distribution of plants of economic importance. The distribution of cotton seed, in 1732, by Philip Miller from the Chelsea Garden to Georgia (the parent stock of npland cotton), the introduction of Para and other rubber plants, and of Cinchona from South America through the agency of Kew, of tea into India by the Calcutta Botanic Garden, may be cited as a few among iunumerable cases. There are those who have expressed the opinion that this function of botanic gardens is now obsolete, but it does not require much reflection to perceive how wide is the field of usefulness still open in the direction of the introduction and distribution of plants. 
Our smaller botanic gardens then may rest content with the attempt to develop their resources on lines best calculated to stimulate interest and promote sound learning, both as centers of education and of research, while it falls to the lot of the larger institutions to display as far as possible the complexity and variety of the vegetable kingdom. The latter, with their herbaria, museums, and laboratories, are responsible to the world for the correctness of the information they supply, since in cases of economic plants incorrect determinations or injudicious advice may involve incalculable harm to the planting community, whose interests they serve.

The magnitude of this responsibility has been fully appreciated, and the results achieved amply serve to demonstrate the success which has attended the efforts of the distinguished botanists who have guided the destinies of our botanic gardens.

"The people will tell of their wisdom and the congregation will shew forth their praise."

\section{Books and Papers Relating to Botanic Gardens}

1. Amberst, Hon. Alicia. A history of gardening in England. London, 1896.

2. Britton, N. L. Botanical gardens. Bull. Torr. Bot. Club 23: 331-345. 1896. Also in N. Y. Bot. Gard., Bull. 1:62-77. 1897.

3. De Candolle, A. P. Notice abbrégee de l'histoire et l'administration des jardins botaniques. Dict. d. Sci. Nat. 24:165-181. 1822. (Unfortunately this account has not been seen.)

4. Holmes, E. M. Horticulture in relation to medicine. Roy. Hort. Soc., Jour. 31: 42-61, 1906 .

5. Jobnson, G. W. A history of English gardening. London, 1829.

6. Kerner von Marilaun, Anton. Die botanischen Gärten, ihre Aufgabe in der Vergangenheit, Gegenwart und Zukunft. Innsbruck, 1874.

7. Maiden, J. H. Functions of a botanic garden, etc. Roy. Soc. N. S. Wales, Jour. and Proc. 46:1-73. 1912. [See pp. 49-73.]

8. Philippi, F. Los jardines botanicos. Santiago de Chile, 1878 .

9. Pulteney, R. Sketches of the progress of botany in England. 2 vols. London, 1790. 


\section{Explanation of Plate}

PLATE 4

Padua Botanic Garden.

Photograph of plate in de Visiani's 'Dell' origine ed anzianita dell' orto botanico di Padova.' Padua, 1839. (See p. 191.) 


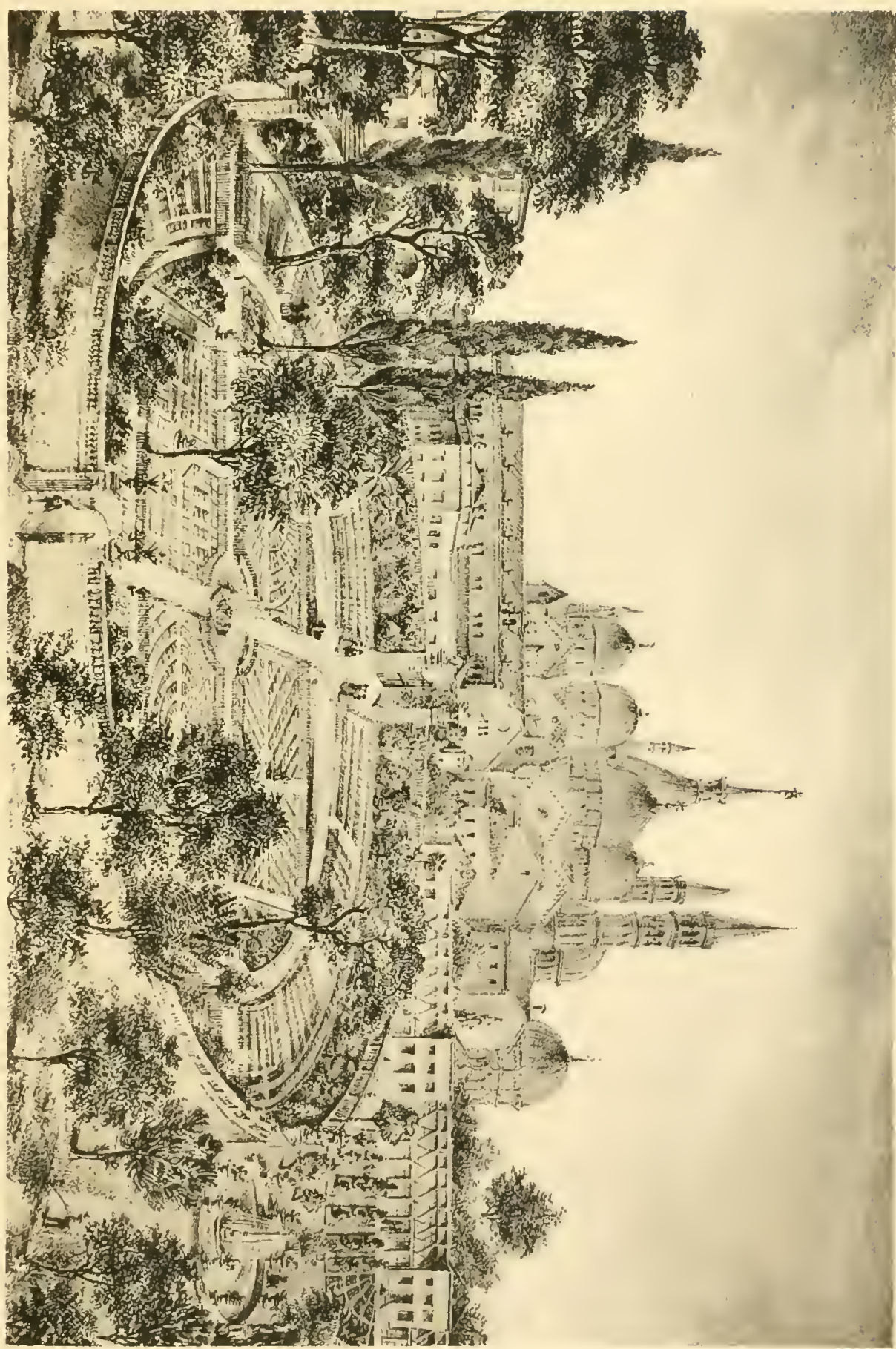




[VOL. 2, 1915]

\section{Explanation of Plate}

PLATE 5

Pisa Botanic Garden.

Photograph of plate in M. A. Tilli's 'Catalogus Plantarum Horti Pisani.' Florence, 1723. (For explanation sec p. 192.) 


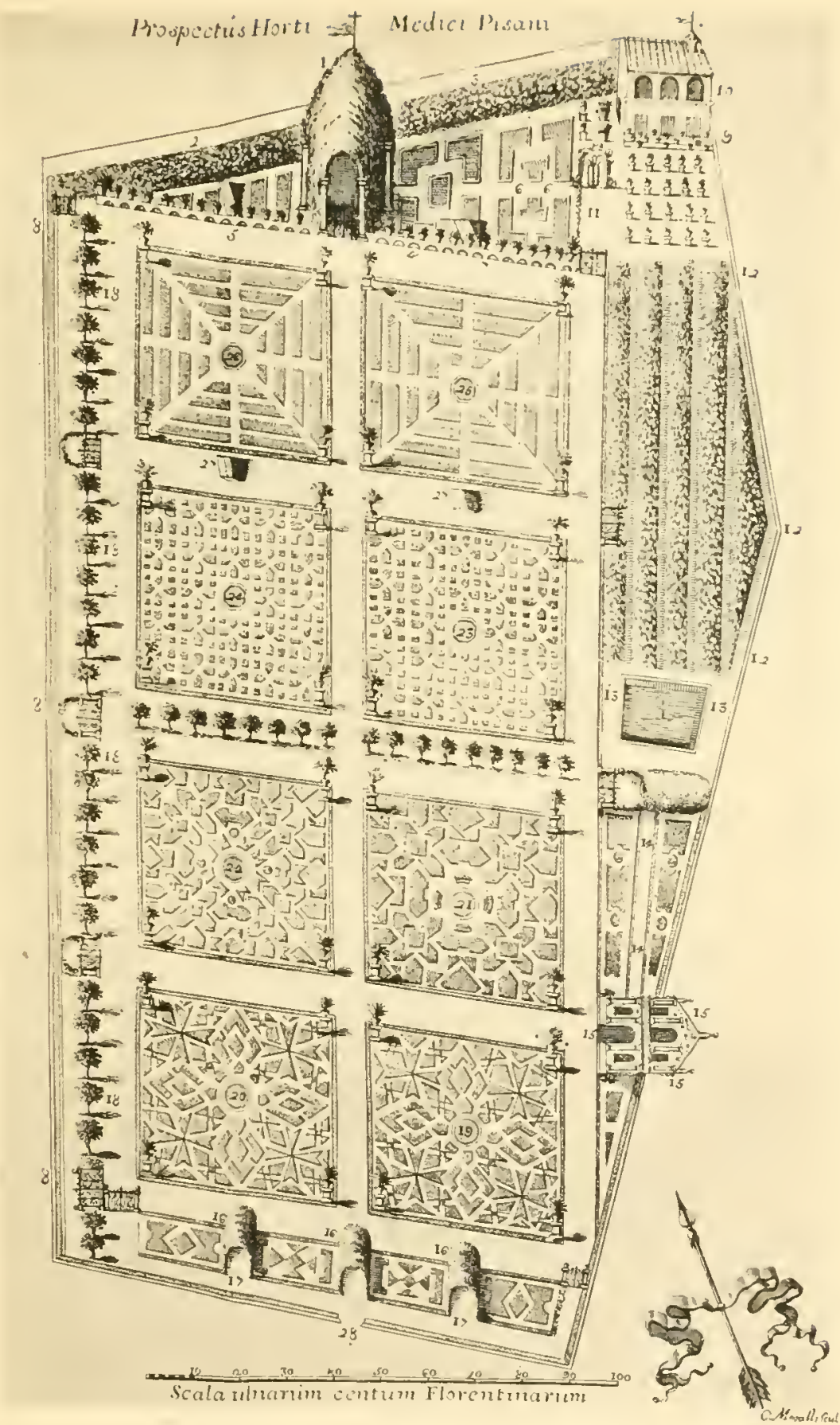

HILL-BOTANIC GARDENS 


Explanation of Plate

PLATE 6

Photograph of title page of Gerard's 'Ilerball.' 1597. (See p. 196.) 


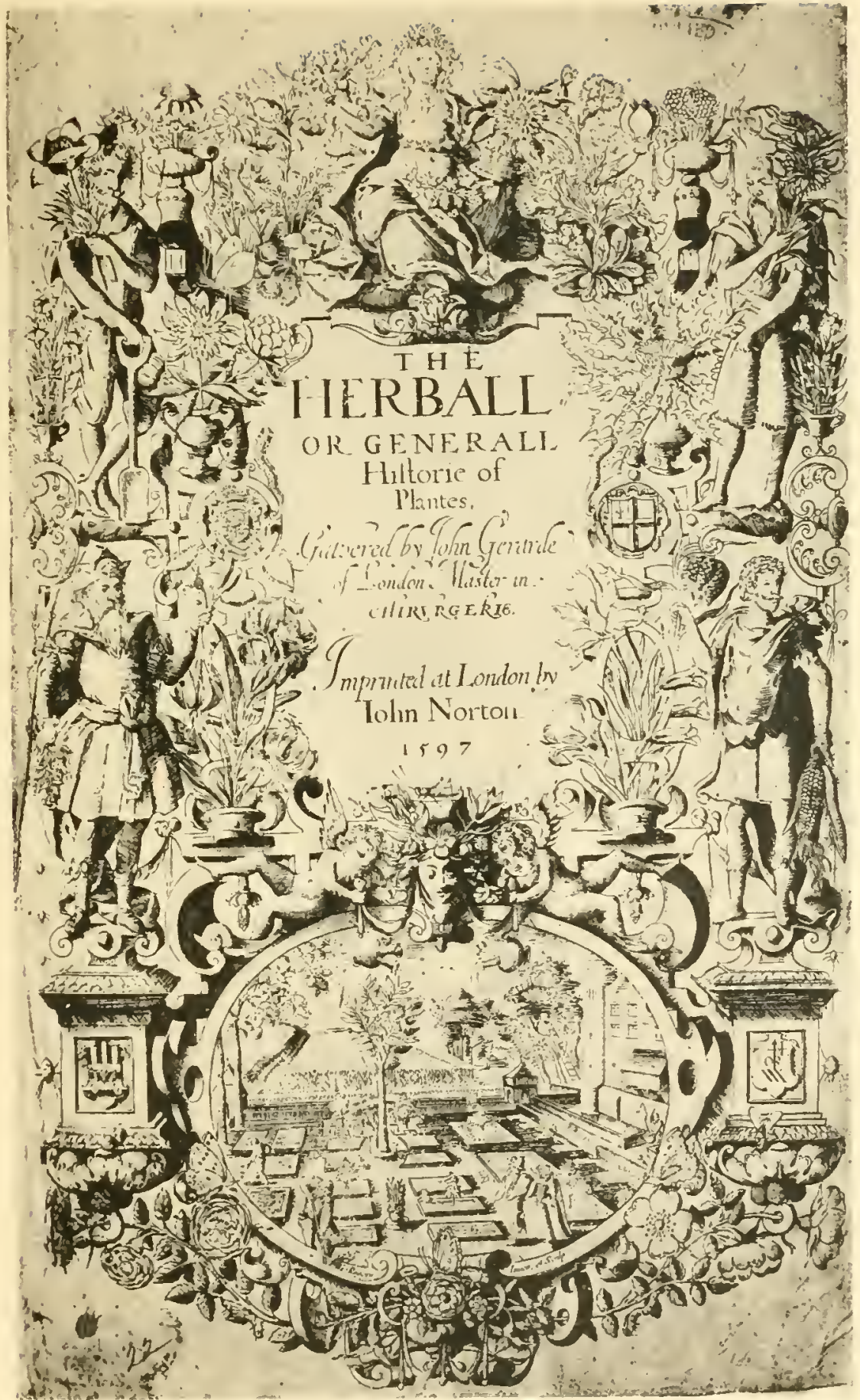






\section{Explanation of Plate}

PLATE 7

Photograph of title page of Parkinson's 'Paradisi in scle Paradisus

Terrestris.' 1656. [2nd ed.] (See p. 197.) 


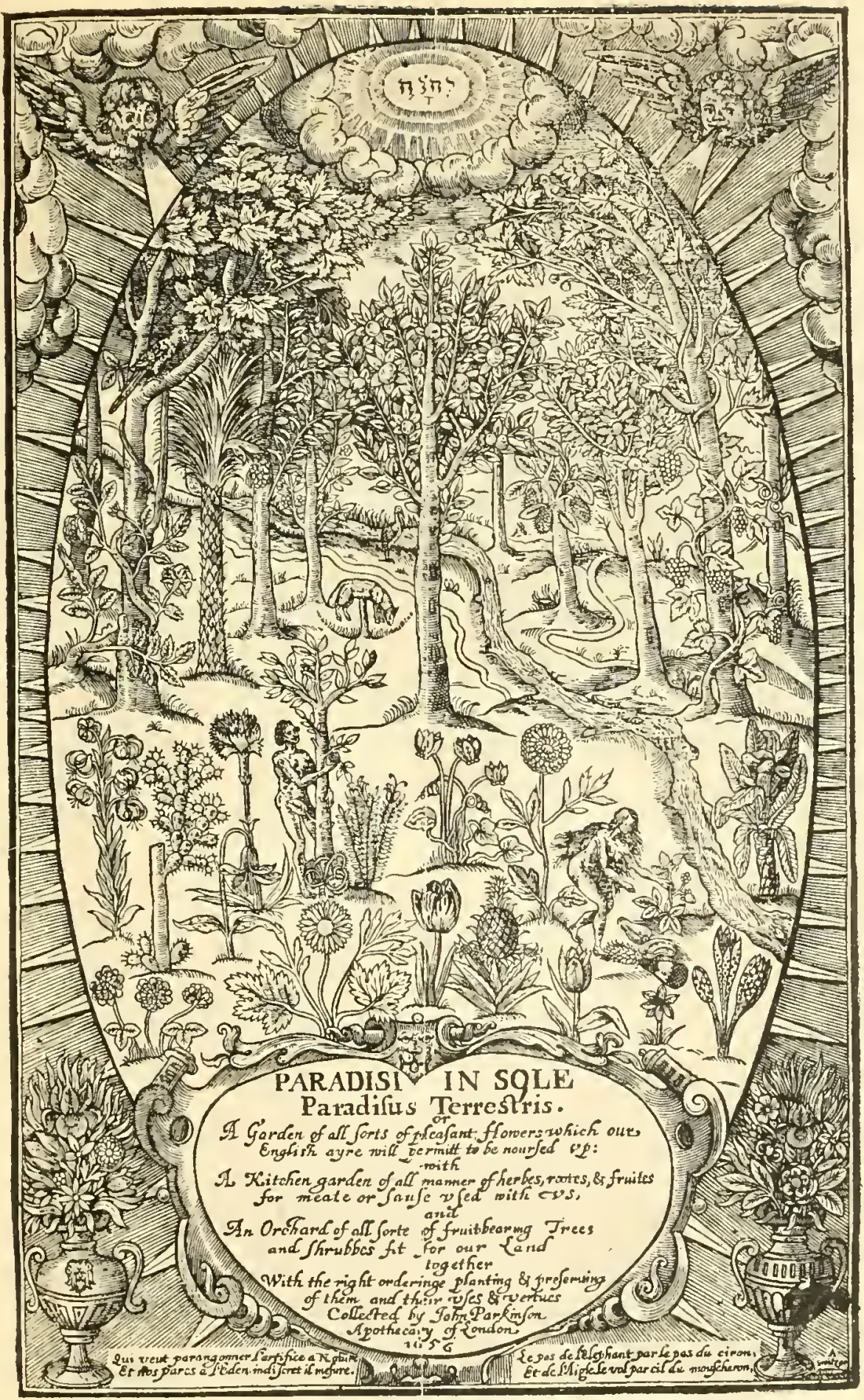

IIILL-BOTANIC GARDENS 



ANNALS OF THE MISSOURI BOTANICAL GARDEN

\section{Explanation of Plate}

PLATE 8

The Oxford Botanic Garden, founded 1621. Reproduced from Loggan's plan of the Garden in 1675. (See p. 197.) 


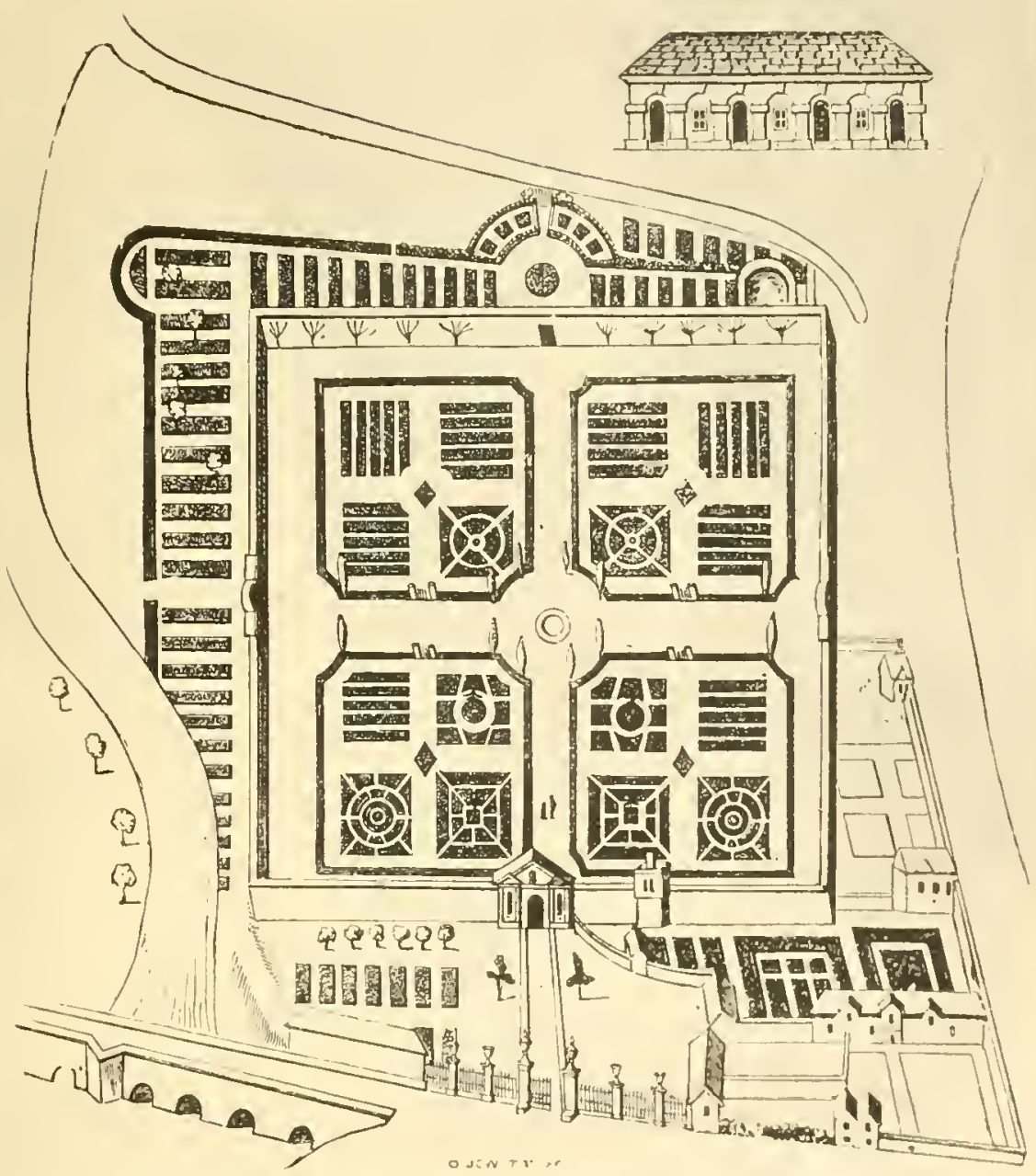

East bridge 




\section{Explanation of Plate}

\section{PLATE 9}

Royal Botanic Gardens, Kew, showing dates and extent of successive additions to the area open to the public and site of the original Botanie Garden of 1760. Photograph of plan in W. J. Bean's 'The Royal Botanic Gardens. Kew,' London, 1908. (See p. 206.)-Published by permission of Cassell \& Co., Ltd. London, England. 


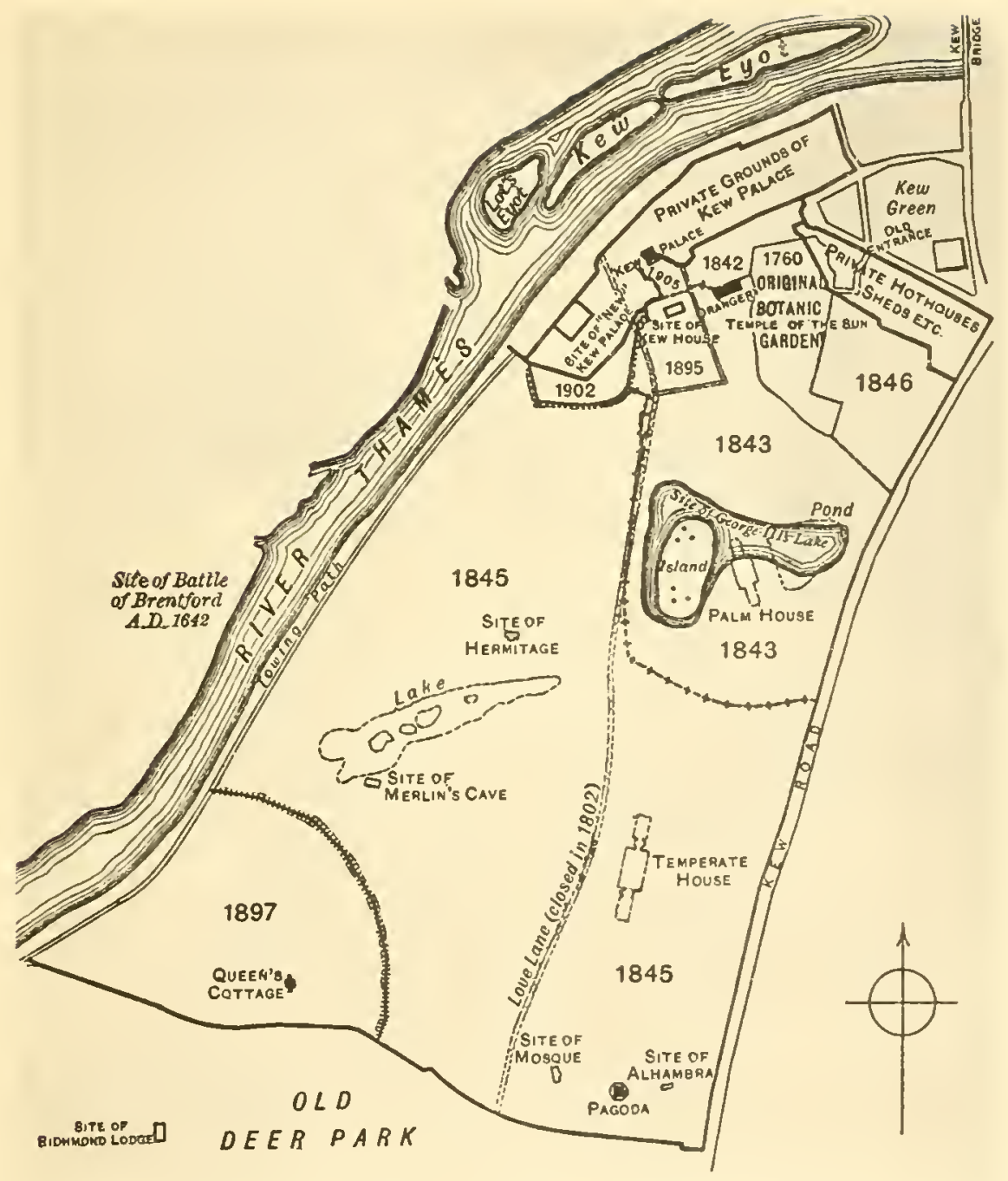






\section{Explanation of Plate}

PLATE 10

The Herbaceous Ground, Royal Botanic Gardens, Kew, showing beds arranged according to the natural orders. 


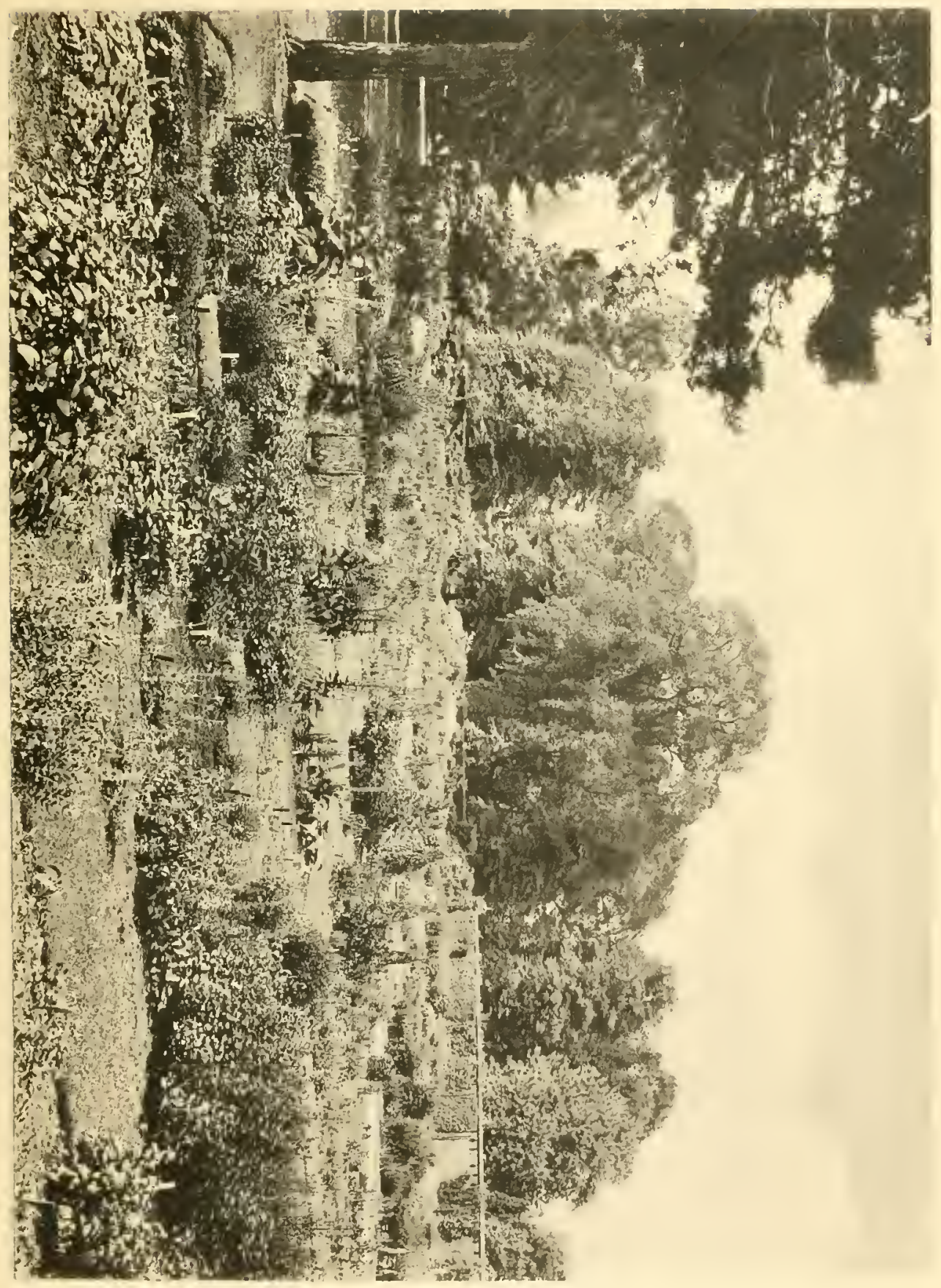






\section{Explanation of Plate \\ PLATE 11}

The Rhododendron Dell, Royal Botanic Gardens, Kew. 


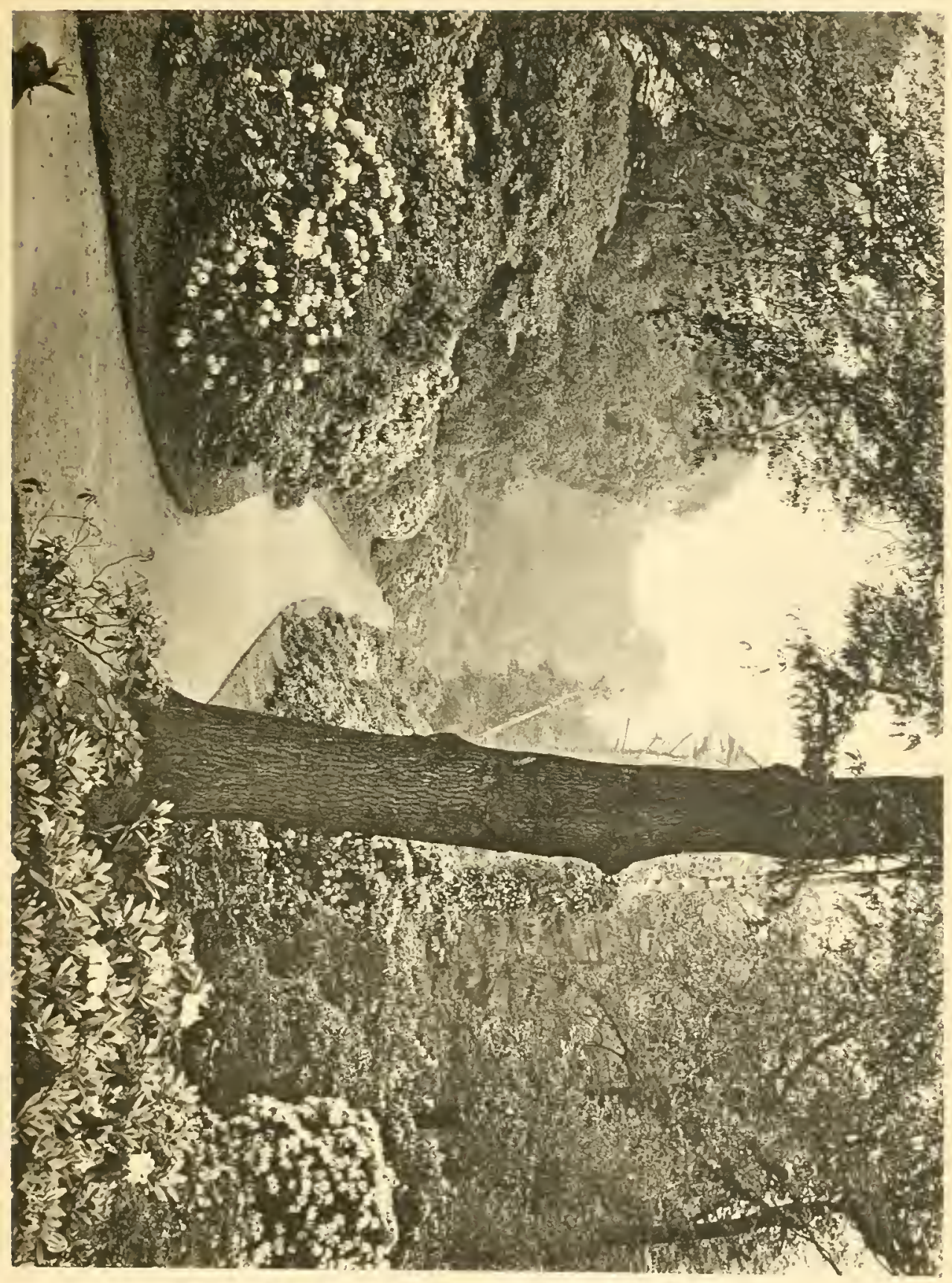






\section{Explanation of Plate}

PLATE 12

The Lake, Royal Botanic Gardens, Kew. 


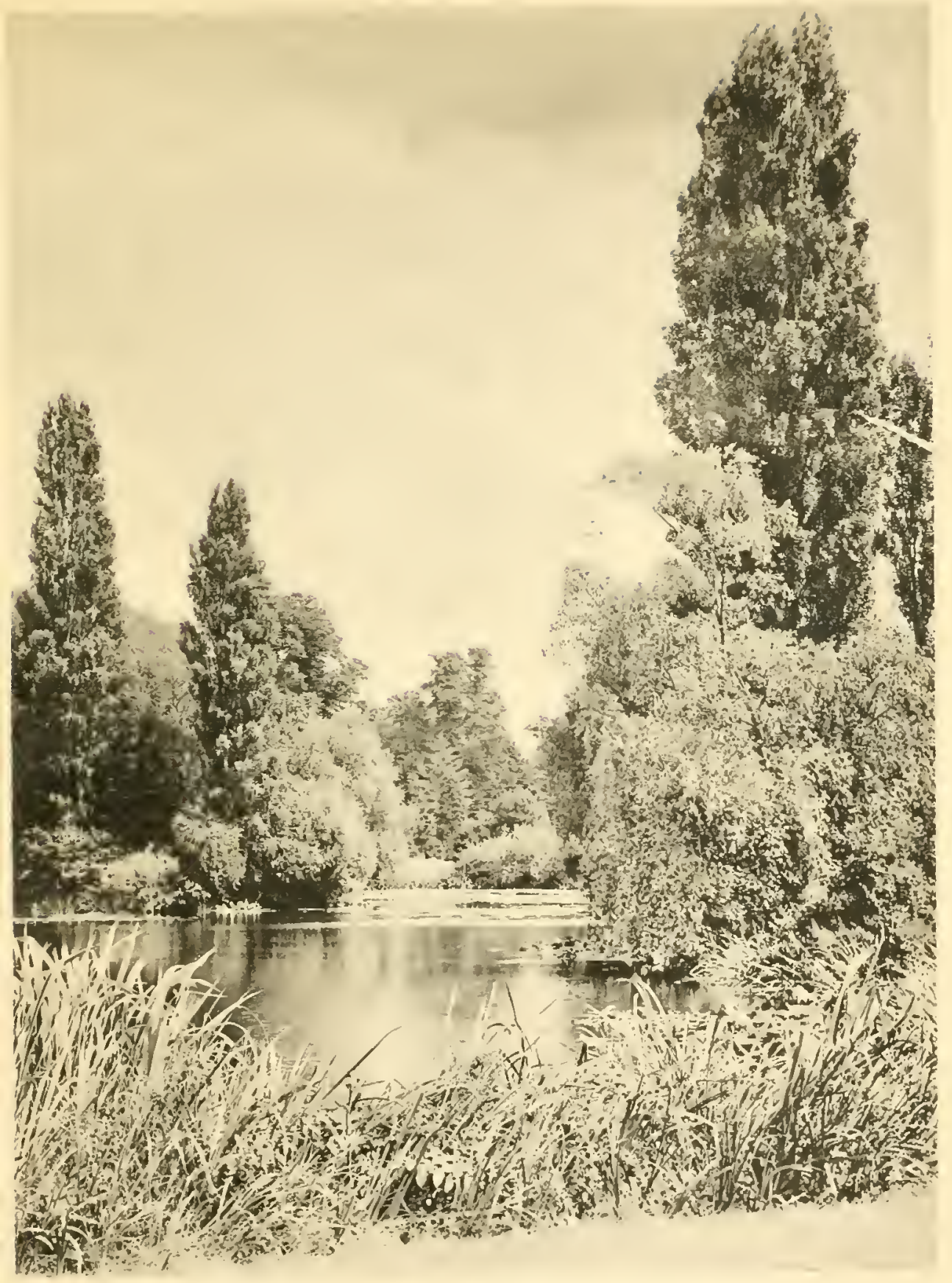






